\title{
Which updates during an equity crowdfunding campaign increase crowd participation?
}

\author{
Jörn Block • Lars Hornuf • Alexandra Moritz
}

Accepted: 30 March 2017 /Published online: 24 May 2017

C) The Author(s) 2017. This article is an open access publication

\begin{abstract}
Start-ups often post updates during equity crowdfunding campaigns. However, little is known about the effects of such updates on crowd participation. We investigate this question by using hand-collected data from 71 funding campaigns and 39,399 investment decisions on two German equity crowdfunding portals. Using a combination of different empirical research techniques, we find that posting an update has a significant positive effect on the number of investments made by the crowd and the
\end{abstract}

J. Block · A. Moritz

Department of Management, University of Trier, Universitätsring 15, 54296 Trier, Germany

J. Block

e-mail: block@uni-trier.de

A. Moritz

e-mail: moritz@uni-trier.de

J. Block

Department of Applied Economics, Erasmus University

Rotterdam, P.O. Box 1738, 3000 DR Rotterdam, Netherlands

J. Block

Erasmus Research Institute of Management (ERIM), Erasmus University Rotterdam, P.O. Box 1738, 3000 DR Rotterdam,

Netherlands

L. Hornuf

University of Trier, Department of Economics, Behringstrasse 21, 54296 Trier, Germany

L. Hornuf $(\bowtie)$

Max Planck Institute for Innovation and Competition,

Marstallplatz 1, 80539 Munich, Germany

e-mail: lars.hornuf@ip.mpg.de investment amount collected by the start-up. This effect does not occur immediately in its entirety; rather, it lags the update by a few days. Furthermore, the effect of updates loses statistical significance with the number of updates posted during a campaign. We also find that an easier language used in updates increases crowd participation, whereas the length of updates has no effects. With respect to the update's content, we find that the positive effect can be attributed to updates about new developments of the start-up such as campaign developments, new funding, business developments, and cooperation projects. Updates on the start-up team, business model, product developments, and promotional campaigns do not have meaningful effects. Our paper contributes to the literature on the effects of information disclosure on equity crowdfunding participation. Furthermore, our results have practical implications for start-ups and their investor communication during equity crowdfunding campaigns.

Keywords Crowdfunding - Entrepreneurial finance . Updates $\cdot$ Investor communication

\section{Introduction}

Equity crowdfunding is an important tool for young and innovative start-ups to collect early-stage funding. Prior research has investigated the success drivers of equity crowdfunding campaigns and has shown that information provided by the start-up, such as the human and social capital of the founders, risks involved, and financial projections, have a positive influence on campaign 
success (Ahlers et al. 2015; Moritz et al. 2015; Vismara 2016b; Polzin et al. 2017). This information usually does not change during a crowdfunding campaign and is typically provided by the start-up before a campaign starts.

Our paper takes a more dynamic perspective than prior research by investigating the role of updates provided by start-ups during an equity crowdfunding campaign. We analyze how start-ups can use updates during the campaign to encourage the crowd to provide funding. This particular determinant of equity crowdfunding participation has been overlooked in the literature so far, and as such, there is an important gap on the effects of information disclosure on crowd participation (Ahlers et al. 2015; Moritz et al. 2015; Bernstein et al. 2017; Vismara 2016b; Polzin et al. 2017). Updates enable start-ups to signal their value to the crowd and to establish credibility and legitimacy during a crowdfunding campaign. We investigate three research questions: First, we analyze whether updates and their frequency have an influence on crowd participation and whether the effect occurs immediately or in a lagged form (Research Question 1 (RQ1)). Second, we investigate how the language complexity used in the updates and the length of the updates affect crowd participation (Research Question 2 (RQ2)). And finally, we look at the content of these updates to determine how the crowd reacts to different signals and information communicated via updates (Research Question 3 (RQ3)). Thus, we not only look at the effects of updates on funding participation per se but also at the effects of specific update characteristics and contents.

To answer our research questions, we investigate updates posted by start-ups during an equity crowdfunding campaign by using hand-collected data from 71 funding campaigns and 39,399 investment decisions on two German equity crowdfunding portals. We find an overall positive effect of posting an update on the number of investments by the crowd and the investment amount collected by the start-up. However, this positive effect does not occur immediately in its entirety; rather, it lags a few days behind the respective update. The effect increases with the ease of language used in the update. Furthermore, we find that the first updates have positive but only marginally significant effects, while the later updates have no significant effects on crowd participation. Large differences exist when distinguishing updates according to their content. Updates that deal with the start-up team, business model, product developments, and campaign promotions do not have meaningful effects on crowd participation. Instead, positive effects on funding participation can be attributed to updates about campaign development, new funding, business developments, and cooperation projects.

Our paper contributes to the entrepreneurial finance literature (for recent overviews see Block et al. 2017a, b). In particular, we contribute to research on the selection criteria of early-stage investors looking at a new type of investor - the crowd. It has been found that specific information, such as education of the entrepreneurial team, protection of intellectual property rights, the venture's network, and firm alliances, are important drivers for the investment decisions of professional early-stage investors such as venture capital funds (Audretsch et al. 2012; Baum and Silverman 2004; Block et al. 2014, 2017a, b; Busenitz et al. 2005; Franke et al. 2008; Jell et al. 2011). It has also been shown that start-ups use this information to signal their value to investors (Audretsch et al. 2012; Block et al. 2014; Connelly et al. 2011). Hence, our paper contributes to research about signals in entrepreneurial finance by looking at the specific context of crowdfunding and crowdinvestors as a new type of venture investor. Furthermore, we add to the growing research on crowdfunding and in particular on equity crowdfunding. Our paper extends this literature by taking a dynamic perspective, investigating how start-ups can signal their value during a crowdfunding campaign using updates as communication tools to increase the likelihood of successful campaigns.

In addition to its contribution to the academic literature, our paper's results also have practical implications for start-ups and crowdfunding platforms. For start-ups, it is worthwhile to learn more about the effects of updates on equity crowdfunding participation. By posting updates, start-ups can actively influence the chances of successfully completing their equity crowdfunding campaigns. Our results show, for example, that the specific content of an update is key, while simply posting more updates has little effect. Knowing which updates drive funding participation is crucial for start-ups to design an effective and successful communication in equity crowdfunding campaigns. For platforms, this information is important to encourage startups to publish updates with content valued by the crowd to increase the likelihood of a successful campaign and ultimately, the platforms' own business success.

The remainder of the paper is organized as follows. The next section provides the theoretical framework of our study and develops hypotheses. Section 3 introduces the data sources and the research techniques used to code and categorize the updates posted by the start-ups during the campaigns. Based on this, we introduce the variables used in the regression analysis and explain our empirical model. 
Section 4 presents the descriptive and multivariate results. The final two sections discuss our results, link them to the crowdfunding and entrepreneurial finance literatures, and summarize our contributions to theory and practice.

\section{Theoretical framework and hypotheses}

\subsection{Signaling theory}

Our theoretical framework is based on signaling theory, which is primarily concerned with reducing information asymmetries between two parties, where the better informed party sends a quality signal to the less informed party (Connelly et al. 2011). In a seminal article, Spence (1973) applied this theory to the labor market, demonstrating how job applicants can use their higher education as effective signals to reduce their potential employers' information deficits. Since then, signaling theory has been used in various research fields such as strategic management, entrepreneurship, labor economics, and human resource management (Connelly et al. 2011). The core concept of signaling theory is summarized in Fig. 1. The key elements are the signaler, the signal, the receiver, and the signaling environment. Signalers are information insiders who possess private information about an individual, a product, or an organization that is not available to outsiders (Spence 1973; Connelly et al. 2011). Signalers deliberately send positive signals to information outsiders to reduce information asymmetries and cause a reaction by the receiver, for example, the investment in a company (Certo 2003; Busenitz et al. 2005). However, for signals to be effective, they need to fulfill two main characteristics: First, they need to be observable because otherwise they would not be perceived by the receiver. Second, signals need to be costly, otherwise they would be too easy to fake or imitate (Spence 1973). Signaler and receiver have - at least in part — conflicting interests: The signaler would gain from sending inferior signals and therefore has an incentive to deceive the receiver (Ross 1977). As receivers are disadvantaged by acting on false signals, they learn to ignore these signals and perceive the signaler as dishonest (Connelly et al. 2011).

Signal effectiveness can be enhanced by communicating signals frequently and with a high signal consistency (Janney and Folta 2003; Fischer and Reuber 2014). This increases the chances that receivers capture the signal and are not confused by different signal contents (Gulati and Higgins 2003; Gao et al. 2008). This is directly related to the role of receivers' characteristics for signal effectiveness
(Perkins and Hendry 2005). In addition to the required attention of receivers to capture the signal, different receivers are likely to interpret signals differently (Perkins and Hendry 2005). This signal translation might even result in a diversion of the signals' original intent (Branzei et al. 2004; Highhouse et al. 2007). Hence, signal clarity is another important characteristic of a signal so that the signaler can achieve the desired effect (Certo 2003; Warner et al. 2006). In this context, countersignals send by receivers as feedback to the signaler can provide additional information about the effectiveness of the signal (Srivastava 2001; Connelly et al. 2011). Finally, the signaling environment can influence the signals' effectiveness. Distortions of the signal can occur, for example, whenever the signal medium reduces its observability (Carter 2006; Fischer and Reuber 2014). In addition, other receivers' interpretation can affect the effectiveness of signals. If a number of receivers interpret signals in a specific way, this might lead to imitation by others (McNamara et al. 2008; Connelly et al. 2011).

2.2 Updates by the start-ups as signals in crowdfunding

\subsubsection{Visibility of updates and its effects on crowd participation}

In the context of entrepreneurial finance, information asymmetries between a start-up's management team and potential investors play a major role. Ventures need to find a way to signal their quality to potential investors to establish legitimacy and credibility and to receive financing (Rao et al. 2008; Zimmerman and Zeitz 2002). In the specific setting of crowdfunding, startups aim to collect capital from a large number of mostly anonymous investors, who contribute small amounts of money via the Internet (Moritz et al. 2015; Belleflamme et al. 2014; Hemer et al. 2011; Hornuf and Schwienbacher 2016). The average crowdfunding investor is not likely to have the time, capacity, and incentive to investigate firms and their business model in detail (Ahlers et al. 2015; Lukkarinen et al. 2016). Due to the specific characteristics of crowdfunding, establishing personal relationships to reduce information asymmetries typical for business angel or venture capital investments (Landström 1992; Sapienza and Korsgaard 1996; Kollmann and Kuckertz 2006) is not feasible in equity crowdfunding markets. Hence, companies need to find alternative ways to communicate their value to the crowd. 


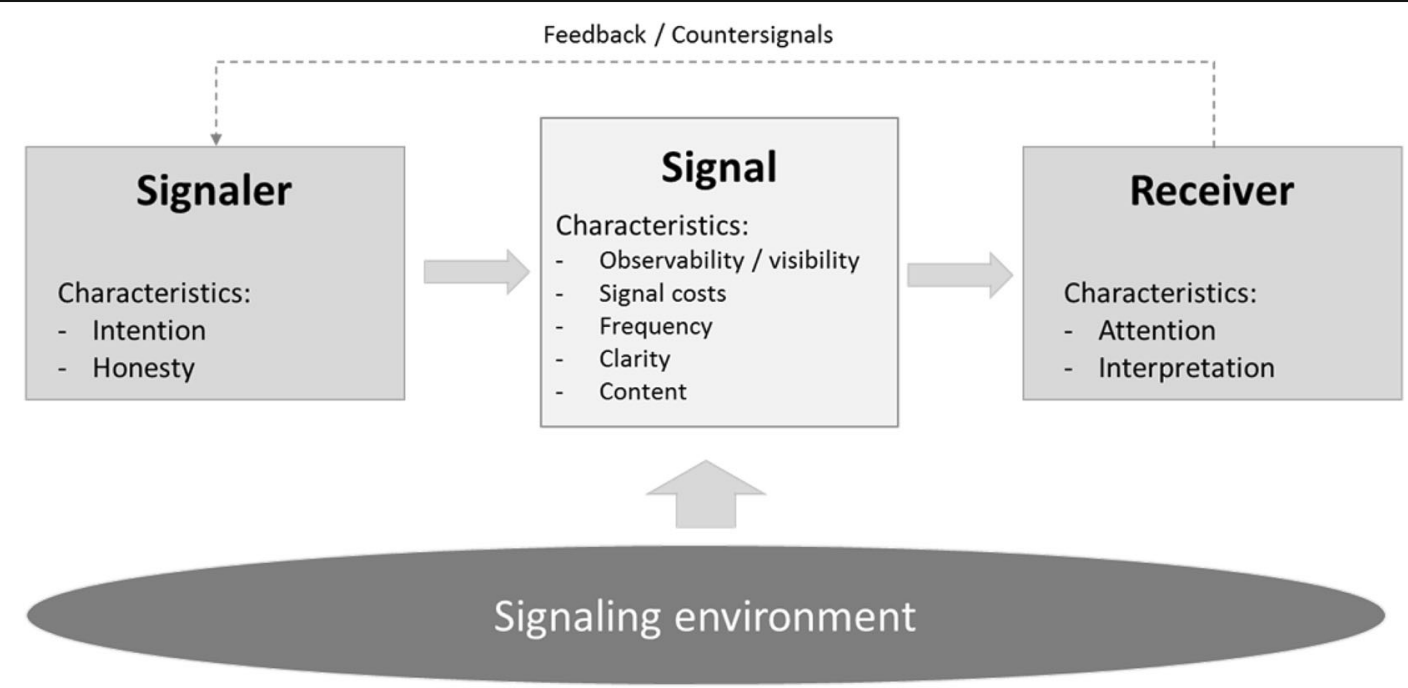

Fig. 1 Concept of signaling theory

Prior research found that updates provided by start-ups can increase funding success (Hornuf and Schwienbacher 2015; Kuppuswamy and Bayus 2017; Mollick 2014; Xu et al. 2014; Wu et al. 2015). Updates are a one-sided communication tool often used during a campaign as it can be applied flexibly by the start-up to provide additional information about the product, the start-up, or the campaign. Hence, referring to the concept of signaling theory (see Fig. 1), our focus in this study is on the signal communicated via updates to convey the start-up's value to the crowd. In line with prior research on reward-based crowdfunding (Mollick 2014; Kromidha and Robson 2016), we propose that updates in general have a positive effect on equity crowdfunding participation as they typically are highly visible and observable for potential investors. Even though updates might not always be costly for the signaler, ${ }^{1}$ they reduce search costs for investors. Hence, we expect:

\section{H1: Updates provided by the start-up have a pos-} itive effect on crowd participation.

However, as updates are posted on the campaign website of the crowdfunding portal, potential investors only see the update if they visit the website. Therefore, start-ups and crowdfunding portals typically also communicate these updates in their social media channels or via

\footnotetext{
${ }^{1}$ As we do not observe the start-ups over a longer time period, we cannot evaluate if the signals send during the campaign are reliable and costly for the signaller. Hence, we have to exclude the cost dimension from our analysis.
}

newsletters to increase investors' awareness of the update. Furthermore, posting an update has typically no immediate effect on crowd participation because investors' need some time to learn about the update and to pledge their money (Wheat et al. 2013; Mollick 2014; Kromidha and Robson 2016; Vismara 2016b). Hence, the visibility of updates and their effect on crowd participation is likely to be delayed by a few days.

\section{H2: The effect of updates on crowd participation does not occur immediately in its entirety but is delayed by a few days.}

In addition, it has been shown that the communication of credible signals is not a static but an ongoing process (Janney and Folta 2003). Signaling can be used to inform investors about the developments of the start-up. The optimal number of signals provided depends on the progress of the start-up since communicating the last credible signal (Janney and Folta 2003). Therefore, we expect using updates regularly to send signals to the crowd has a positive effect on equity crowdfunding participation. However, during a crowdfunding campaign which typically has a funding period of around two months, new developments which can be communicated to investors are limited. An increasing number of updates might even be perceived by investors as unreliable or cheap talk as no further information value can be delivered (Perkins and Hendry 2005; Block et al. 2014). Therefore, we expect that the marginal value of updates will decrease as the updates no longer provide much additional value to potential investors 
(Janney and Folta 2003, 2006; Block et al. 2014). Hence, we suggest that a negative relationship exists between the number of updates posted and their effect on crowd participation:

H3: The effect of updates on crowd participation decreases with the number of updates posted by the start-up.

\subsubsection{Clarity of updates and its effects on crowd participation}

Signaling theory has shown that signals need to be visible and clear so that market participants are able to capture the information content of the signal (Certo 2003; Warner et al. 2006). The clarity of the signal directly relates to the interpretation by receivers: Members of a group of very heterogeneous receivers are more likely to translate the signal differently (Perkins and Hendry 2005; Connelly et al. 2011). As the receivers of signals in crowdfunding markets have been found to be very heterogeneous (Ahlers et al. 2015), the clarity of the signal is particularly important. Clarity, however, depends on the complexity of the language used in the updates. Hence, we propose that updates using a complex language are more difficult to understand, loose clarity and therefore their effectiveness as a signal:

H4: The effect of updates on crowd participation decreases with the complexity of the language used in the update.

Furthermore, previous research found that the length of descriptions in crowdfunding campaigns have a significant positive effect on the campaign outcome (Greiner and Wang 2010; Gao and Lin 2014). Longer descriptions can deliver more information about the project, the start-up, or the product and can help to reduce information asymmetries between the start-up and potential investors. Hence, we propose:

H5: The effect of updates on crowd participation increases with the length of the update.

\subsubsection{Content of updates and its effects on crowd participation}

Prior research in entrepreneurial finance found that the content of signals provided by the start-up plays an important role.
Ventures can use a number of different signals to reduce information asymmetries by communicating their value to potential investors, such as the entrepreneurial team education, intellectual property rights, and the share of retained equity (Audretsch et al. 2012; Baum and Silverman 2004; Block et al. 2014; Busenitz et al. 2005).

Even though crowdfunding research is still young, a number of different signals have been found to have a positive effect on crowd participation. However, it needs to be considered that investors' motivations have been shown to depend on the specific crowdfunding model (Cholakova and Clarysse 2015; Lukkarinen et al. 2016; Vulkan et al. 2016; Polzin et al. 2017), which suggests that the effects of updates and the signals used also differ according to the crowdfunding model. Focusing on findings in relation to venture financing with a profit participation of investors, the content of these signals can be roughly summarized into information about the start-up's quality (i.e., the management team, its preparedness and openness, and the start-up's financials) and external credentials provided by third parties (i.e., through social networks, reputable investors, protection of intellectual property, reception of grants, and the reaction by the crowd). Table 1 provides an overview of the findings from prior crowdfunding research.

However, none of these studies focuses on the dynamic aspects of providing new and ongoing signals to investors using updates during equity crowdfunding campaigns. Our study is - to the best of our knowledge - the first to look into this important research question.

We refrain from ex ante assumptions and use an exploratory approach and formulate the following open research question: "How does the type of content provided in the update influence crowd participation?". Figure 2 summarizes our three research questions and hypotheses.

\section{Data and method}

\subsection{Data sources}

Our empirical analysis uses data from two German equity crowdfunding portals over the period from June 7, 2012, to April 27, 2015. The two portals are Seedmatch and Companisto, which are important players in the German equity crowdfunding market and together represent about $75 \%$ of the overall crowdfunding capital 
Table 1 Prior research about the effects of signals in equity crowdfunding

\begin{tabular}{|c|c|c|c|c|}
\hline Category & Signals & Effect & Reference to & Study \\
\hline \multirow[t]{2}{*}{ Team } & $\begin{array}{r}\text { Management team's } \\
\text { education (MBA) }\end{array}$ & + & Quality disclosure & Ahlers et al. (2015) \\
\hline & Soft facts & + & Openness; transparency & Moritz et al. (2015) \\
\hline \multirow[t]{2}{*}{ Financials } & $\begin{array}{l}\text { Financial information about } \\
\text { the start-up }\end{array}$ & + & Quality disclosure; preparedness & $\begin{array}{l}\text { Ahlers et al. (2015), Lukkarinen et al. (2016), } \\
\text { Polzin et al. (2017) }\end{array}$ \\
\hline & Share of retained equity & Mixed & Entrepreneurial intention & $\begin{array}{l}\text { Ahlers et al. (2015), Ralcheva and } \\
\text { Roosenboom (2016), Vismara (2016a) }\end{array}$ \\
\hline \multirow[t]{5}{*}{$\begin{array}{l}\text { External } \\
\quad \text { certification }\end{array}$} & Social network (size) & Mixed & $\begin{array}{l}\text { Social capital; quality disclosure; } \\
\text { larger investor base }\end{array}$ & $\begin{array}{l}\text { Ahlers et al. (2015), Lukkarinen et al. (2016), } \\
\text { Vismara (2016a) }\end{array}$ \\
\hline & $\begin{array}{l}\text { Reputable investors } \\
\text { (business angels, experts) }\end{array}$ & + & Quality disclosure; certification & $\begin{array}{l}\text { Kim and Viswanathan (2013), Ralcheva and } \\
\text { Roosenboom (2016) }\end{array}$ \\
\hline & $\begin{array}{l}\text { Investors with large } \\
\text { investments }\end{array}$ & + & Quality disclosure & Vulkan et al. (2016) \\
\hline & Intellectual capital (patents) & Mixed & Quality disclosure & $\begin{array}{l}\text { Ahlers et al. (2015), Ralcheva and } \\
\text { Roosenboom (2016) }\end{array}$ \\
\hline & Reception of grants & None & Quality disclosure & Ralcheva and Roosenboom (2016) \\
\hline \multirow[t]{2}{*}{$\begin{array}{l}\text { Campaign } \\
\text { developments }\end{array}$} & Funds already raised & + & $\begin{array}{l}\text { Social capital; observational } \\
\text { learning }\end{array}$ & Agrawal et al. (2015), Vulkan et al. (2016) \\
\hline & Number of capital providers & + & $\begin{array}{l}\text { Social capital; observational } \\
\text { learning }\end{array}$ & Mohammadi and Shafi (2017) \\
\hline
\end{tabular}

raised during our observation period. For Companisto, we hand collected data on all 36 campaigns that were completed until the end of the observation period. For Seedmatch, we were able to hand collect data on 29 of 78 campaigns. We could collect investment data on only about half of the campaigns for Seedmatch because the portal takes information about individual investments immediately off the website once the campaign terminates. We therefore could not collect data for the campaigns that ended before June 7, 2012. For some campaigns, we were simply too slow to hand collect the data from the website.

Some start-ups such as Meine-Spielzeugkiste ran two campaigns on the same portal. Furthermore, Aoterra,

\section{Equity crowdfunding}

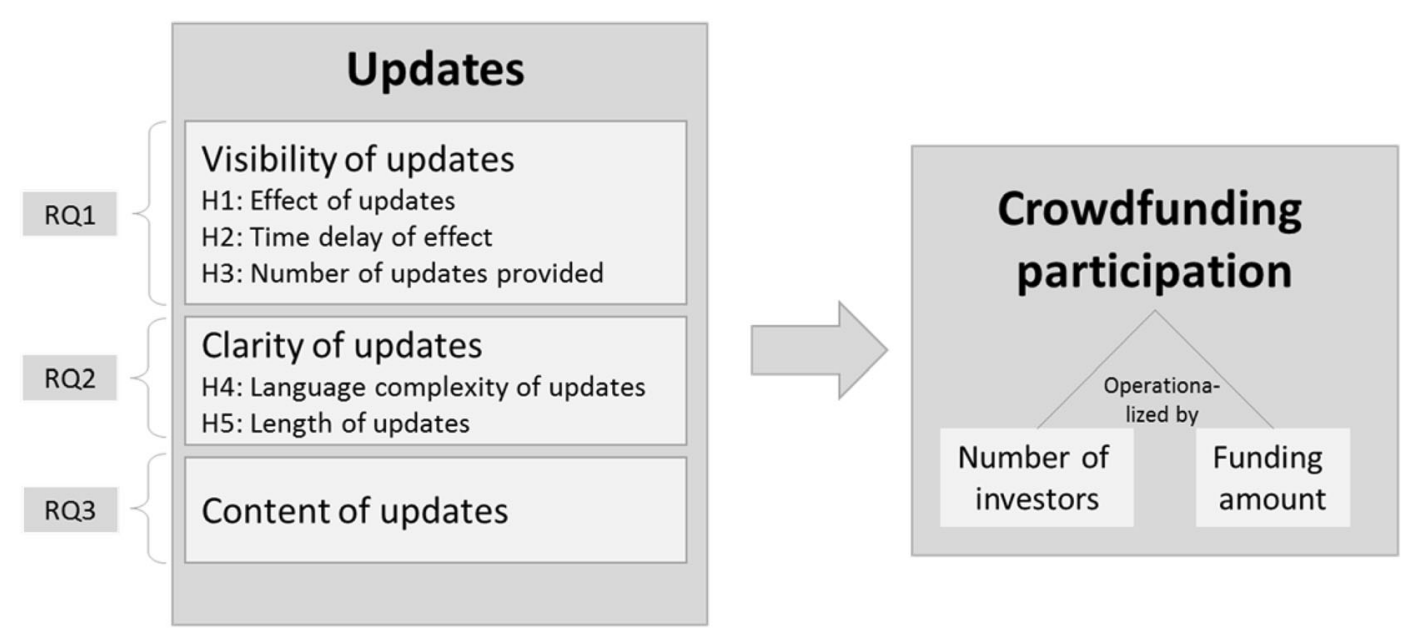

Fig. 2 Research questions (RQ) and hypotheses 
Controme, Ledora, Payme, Protonnet, and Riboxx reached their respective funding limits quickly and subsequently decided to raise more capital. On average, it took these start-ups six days to initiate the campaign again. We have counted these rounds as independent campaigns, as investors could not anticipate that a second round would quickly follow the end of the first round and thus most likely did not adapt their investment behavior accordingly. Overall, we were able to analyze 39,399 investment decisions within 71 unique funding campaigns. In line with Kuppuswamy and Bayus (2017), we then constructed a panel data set that aggregates the number of investments in a particular campaign on a given day. The time dimension of the panel data set is the duration of the campaign in days, while the cross-sectional dimension refers to the campaigns.

\subsection{Dependent variables}

In our empirical analysis, we use two different dependent variables: the number of investments and the amount of capital pledged during an equity crowdfunding campaign on a given day. This allows us to investigate the effects of updates on the number of crowd investments as well as the amount of money pledged.

\subsection{Explanatory variables}

To investigate $\mathrm{H} 1$ and $\mathrm{H} 2$, we consider the variable Update, which measures the number of updates posted during a campaign on a given day. In different specifications, the variable is lagged by 1 day or alternatively measures the number of updates that were posted during the course of one week. To investigate the frequency by which a start-up posts updates during the course of a campaign as outlined in $\mathrm{H} 3$, we consider the variable Update Number, which captures the number of updates that have been previously posted by the start-up during a particular crowdfunding campaign. Furthermore, to investigate $\mathrm{H} 4$, we use the Flesch Readability Index (Flesch Index) that measures the language complexity of an update (Flesch 1948). More precisely, we use the "reading ease" rating of the Flesch index defining a seven-item scale, where 1 corresponds to a Flesch index of 0-30 (very difficult language) and 7 to a Flesch index of 91-100 (very easy language) (Courtis 1995; Flesch 1948). Finally, in order to test H5 we consider the variable Words, which captures the text length of an update.

To identify the information included in the updates posted by the start-up, we develop a coding system that categorizes the information contained in the campaign updates. For this purpose, we used the software package MaxQDA, which allowed us to analyze qualitative data. In a first step, we generated an initial list of update categories based on our prior knowledge and previous research on investment decisions in equity crowdfunding (Hornuf and Schwienbacher 2015; Moritz et al. 2015; Moritz and Block 2015; Vismara 2016a, 2016b). During the coding process, we expanded this initial coding system by using an iterative and inductive process to cover all relevant information provided by the updates (Miles and Huberman 1994). Then, we merged similar categories and finally developed a system of categories with higher dimensions (Gioia et al. 2012; Miles and Huberman 1994). Our final coding system consists of nine categories of updates: Team, Business Model, External Certification, Product Development, Cooperation Projects, Campaign Development, New Funding, Business Development, and Promotions.

The category Team contains all the information about the start-up's founders and employees, such as their education, age, and personal interests. In the category Business Model, we coded updates on the start-up's business model, market, business idea, future business orientation, and expansion aspirations. External Certification comprises updates where the start-ups informed investors about external certification through expert opinions, recommendations, awards won by the startup, patent applications, press coverage, and participations at trade fares, conferences, or organized talks. The category Product Development contains information about the start-up's product, target customers, new product innovations, and introduction of prototypes. Information about new cooperation projects by the start-up is coded in the category Cooperation Projects. Campaign Development contains information about developments of the crowdfunding campaign, such as the current number of investors, funding amount, and announcements about increases in the funding limit. Financing provided by other market participants, such as business angels, venture capitalists, or the government (i.e., public grants or subsidies), is included in the category New Funding. The category Business Development contains information about the financial development of the start- 
up (e.g., sales development and turnover) as well as customer updates (e.g., the number of customers or new customers). Finally, the category Promotion contains information about promotions, networking via social media, current events to meet crowd investors and appeals to investors to support the company with marketing activities or recommendations. A detailed overview of the categories, including some examples, is provided in Table 5 of the Appendix.

To ensure that our coding system is reliable and coherent, detailed explanations were provided for each category. Then, a second researcher, who was not involved in the project, coded $20 \%$ of the updates. This allowed us to ensure that the coding categories were exhaustive and that they have a high degree of objectivity. The inter-rater reliability using Cohen's Kappa indicated good agreement between us and the external researcher (the average Cohen's Kappa for all categories was 0.65) (Fleiss et al. 2003; Landis and Koch 1977). To permit even higher consistency in the coding, the coding system was then discussed with the external researcher and adapted when necessary. Afterwards, both researchers coded again all 234 updates of the 71 equity crowdfunding campaigns. Once again, an inter-rater reliability analysis was conducted to ensure coding consistency between the researchers. Again, we used Cohen's Kappa as a statistical measure of inter-rater reliability for the coding of the nine main update categories. Cohen's Kappa for the individual categories ranged from 0.70 to 0.96 ; the average Cohen's Kappa of 0.84 for all categories indicates excellent agreement between us and the external researcher.

\subsection{Control variables and fixed effects}

Following prior research on funding dynamics in equity crowdfunding (Hornuf and Schwienbacher 2015; Vismara 2016b), we included several control variables in our baseline regression. To account for campaign participation before the focal day, we control for the amount of capital raised during the crowdfunding campaign until the previous day $\left(\operatorname{Ln}(\text { Amount })_{0 \rightarrow t-1}\right)$. While this variable indicates how much capital has already been invested, it does not capture how many investors supported the campaign and whether more investors might provide a signal regarding the collective wisdom of the crowd. Since we cannot uniquely identify investors across portals by using their name and location (i.e., there might be two or more Thomas Mueller living in Munich and investing on the two portals), we consider the number of investments to be the best available proxy for the number of investors that have invested until the previous

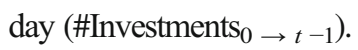

Hornuf and Schwienbacher (2015) show that investments slow down under first-come, first-serve funding mechanism once the funding goal is reached. We therefore include the dummy variable Post Funded, which equals 1 if the funding goal is reached and 0 otherwise. In line with Cumming and Zhang (2016) as well as Kuppuswamy and Bayus (2017), we include a variable that captures the number of active campaigns across four major German equity crowdfunding portals, including the two portals in our data set as well as Innovestment and United Equity (Active Campaigns). ${ }^{2}$ Similarly, we include a variable that captures the number of investments made on these four portals on a given day (Competing Investments). This variable is included to capture potential "Blockbuster Effects" (Kickstarter 2012; Doshi 2014), where a popular and widely visible campaign steals investors away from other campaigns. Vismara (2016a) shows that equity retention influences crowdfunding success. Since start-ups on German equity crowdfunding portals do not issue equity shares but some mezzanine form of investment (equity shares are too expensive to transfer as a costly notary must be involved and the platform requires an authorization by the German Securities Regulator), we calculate the quasi-equity share offered to the crowd. This is the percentage of the minimum amount of capital requested over the pre-money valuation of the start-up ( $E q$ uity Share). Finally, to control for portal characteristics, we include a dummy variable (Seedmatch) that is equal to 1 if the campaign is run on Seedmatch and 0 if it is run on Companisto.

However, given that we might not have controlled for all relevant explanatory variables, we also consider a range of fixed effects. First, we include campaign fixed effects as they help us to remove any time-invariant heterogeneity from the focal campaign, such as the type of financial contract used, specific clauses that have been defined, or the industry of the start-up. Second, we include various fixed effects that capture the time of the investments, such as the day of the week, the month of the year, the respective year, and the day of the funding cycle. While endogeneity in the form of missing

\footnotetext{
${ }^{2}$ We do not consider the portals Innovestment and United Equity in our analysis, as the former does not allow founders to post updates on the portal website and because we simply did not observe updates during the running of the campaigns for the latter.
} 
variables is an inevitable problem in empirical research, the controls we consider here should capture the most relevant observable and unobservable missing variables.

\subsection{Empirical models}

Because the first dependent variable is measured as a count variable and because its unconditional variance suffers from overdispersion, we estimate a neg- ative binomial regression model. The results of a Hausman test led us to dismiss the random-effects estimator as being inconsistent. We therefore estimate a fixed effects negative binomial (FENB) model, which is a pseudo panel estimator that allows us to include time-invariant measures into the regression, such as the variables Equity Share and Seedmatch. In our baseline specification, we estimate the following FENB model:

$$
\begin{aligned}
\operatorname{Pr}\left(y_{i 1}, y_{i 2}, \ldots y_{i \mathrm{~T}}\right) & =F\left(\operatorname{Ln}(\text { Amount })_{i, 0 \rightarrow t-1}+\text { Investments }_{i, 0 \rightarrow t-1}+\text { Post Funded }_{i t}+\text { Number of Active Campaigns }_{t}\right. \\
& + \text { Number of Competing Investments }_{t}+\text { Post Funded }_{i t}+\text { Equity }_{\text {Share }_{i}}+\text { Seedmatch }_{i} \\
& \left.+ \text { Update }_{i t}+\text { Update Number }_{i t}+\mathbf{D o W}_{t}+\mathbf{M o Y}_{t}+\text { Year }_{t}+\text { DoIC }_{i t}+\text { Campaign }_{i}\right)
\end{aligned}
$$

where $y$ is the number of investments in campaign $i$ on day t. $F($.) represents a negative binomial distribution function as in Baltagi (2008). We specify campaign fixed effects denoted by Campaign. DoW is a vector of dummies that indicates the day of the week. MoY is a vector of dummies for the month of the year. Year is a vector of dummies for the respective years. In line with Kuppuswamy and Bayus (2017), DoIC is a vector of dummies that indicates the first and the last 7 days of the funding campaign.

For the second dependent variable, which measures the amount of capital that was pledged on a given day, we run a simple OLS panel regression. The results of a modified Hausman test again led us to dismiss the random-effects estimator as being inconsistent. We therefore run a standard OLS fixed effects panel data model. However, this model does not allow us to identify time-invariant campaign effects, as the time-invariant heterogeneity will be differenced out by the estimator. We therefore can no longer identify the effect of the variables Equity Share and Seedmatch. The baseline OLS model takes the following form:

$$
\begin{aligned}
\operatorname{Ln}\left(\text { Amount }_{i t}\right. & =\operatorname{Ln}(\text { Amount })_{\mathrm{i}, 0 \rightarrow t-1}+\text { Investments }_{\mathrm{i}, 0 \rightarrow t-1}+\text { Post Funded }_{i t}+\text { Number of Active Campaigns }_{t} \\
& + \text { Number of Competing Investments }_{t}+\text { Post Funded }_{i t}+\text { Update }_{i t}+\text { Update Number }_{i t} \\
& + \text { DoW }_{t}+\text { MoY }_{t}+\text { Year }_{t}+\text { DoIC }_{i t}+\text { Campaign }_{i t}+\mathrm{u}_{i t} .
\end{aligned}
$$

\section{Results}

\subsection{Descriptive statistics}

For the 71 equity crowdfunding campaigns over the period from June 7, 2012, to April 27, 2015, we observe 5210 campaign days, which are defined as days when investors had the opportunity to invest in a specific equity crowdfunding campaign. Overall, the start-ups running these campaigns posted 234 updates, with an average of 3.30 updates per campaign. However, while some start-ups did not post a single update, others have extensively used this tool to inform the crowd and encourage investor participation. During the campaign of MyParfum, for instance, a 
total of 14 updates were posted. Interestingly, some update categories were posted more frequently than others. For example, investors were more often informed about the business model, promotional campaigns, the latest product developments, and the external certifications of the start-up than about recent campaign developments or the start-up team. Start-ups rarely disclosed updates on new funding. During most of the campaign days, no update was posted. Every 25 days, start-ups posted an update and occasionally even two updates were posted on the same day. The mean update contained 289 words (median: 248 words).

The 71 campaigns in our sample were run by 63 unique start-ups. Some start-ups ran multiple campaigns on different or sometimes the same portal. All of these start-ups are located in Germany. Most of them operate in the information and communication, wholesale and retail, as well as manufacturing sectors. Regarding the campaign development, on $86 \%$ of the campaign days, the start-ups had already surpassed the funding goal, and the founders of the start-up thus knew that they would ultimately receive the capital (Post Funded). Table 2 also shows that, on average, 7.56 investments were made on a campaign day and that $5886.74 €$ were pledged by the crowd. On some days, the crowd invested as much as 1.5 million $€$ in a single campaign, while on other days, they withdrew $10,000 €$ of investments. On average, 436.85 investments were made before an investor decided to invest. On a given campaign day, 40.37 investments were made in the overall market, and 6.55 campaigns were run in addition to the campaign under consideration. Table 6 in the Appendix shows a correlation table that includes the dependent variables and the main explanatory variables.

\subsection{Results of the baseline regression models}

Table 3 shows the regression results for our baseline models. For the FENB model, we report incident rate ratios, which can be interpreted as multiplicative effects or semielasticities. ${ }^{3}$ In line with prior research (Hornuf and

\footnotetext{
${ }^{3}$ For example, the coefficient of Competing Investments in Table 3 Model 1 is 1.08. It indicates that an increase of the explanatory variable (which is measured in 100 competing investments) corresponds to a 1.08 times change in the dependent variable. In this case, the dependent variablethe number of investments per day-increases by $8 \%$ if 100 more competing investments are made in other campaigns. On the other hand, the coefficient of \#Investments (which is measured in 100 previous investments) is 0.91 . This time, the coefficient indicates that an increase of the explanatory variable corresponds to a 0.91 times change in the dependent variable. Thus, the dependent variable decreases by $9 \%$ if 100 more investments are made by the crowd until the previous day.
}

Schwienbacher 2015), we find that 100 additional investments until the previous day reduce the number of investments on a given day by $9 \%$ and the amount invested by $32 \%$. Once the campaign was successfully funded, the investment amounts on a given day decrease on average by $63 \%$. Moreover, when other campaigns received 100 additional investments, the campaign under consideration received $8 \%$ more investments and $24 \%$ more capital was pledged. This finding may result from a general boom in the equity crowdfunding sector after periods of extensive media coverage positively reporting about this method of financing. Portal differences exist, with Seedmatch campaignsdepending on the specification - attracting on average 60 to $82 \%$ fewer investments than Companisto campaigns, which is most likely due to the fact that the minimum investment ticket of Seedmatch is 50 times larger than the $5 €$ minimum ticket of Companisto. Furthermore, while the day of the week dummies show that less investment activities take place during the weekend and that the campaign days follow the L-shaped pattern as described in Hornuf and Schwienbacher (2015), no consistent pattern emerges for any of the other fixed effects.

In accordance with $\mathrm{H} 1$, we find that updates positively influence crowd participation. While the effect does not take place immediately, we locate a significant effect for the number of investments the following day. Furthermore, updates posted over the course of 1 week do not only influence the number of investments but also the amount invested, with one more update increasing the number of investments by $16 \%$ and the amount invested by $40 \%$. We interpret this as strong support for our $\mathrm{H} 1$ and $\mathrm{H} 2$. In a next step, we investigate whether the frequency by which updates are posted exhibits a particular relationship. Figure 3 reports the predictive margins for the number of updates posted during a campaign. It shows that while the effect is positive except for such high numbers as 14 updates, the standard errors are steadily increasing with the number of updates, stifling any statistically significant effect as more updates are posted. Thus, we do not find support for H3.

\subsection{Update categories and their effect on crowd participation}

First, as outlined in RQ2 and RQ3, Table 4 investigates how the complexity of the language used in updates, the length of the updates, and the content of updates influences crowd participation. As in the previous regressions, we do not find any immediate 
Table 2 Summary statistics

\begin{tabular}{|c|c|c|c|c|c|c|c|c|}
\hline Variable & Mean & Median & $\begin{array}{l}\text { Std. dev. } \\
\text { (overall) }\end{array}$ & $\begin{array}{l}\text { Std. dev. } \\
\text { (between) }\end{array}$ & $\begin{array}{l}\text { Std. dev. } \\
\text { (within) }\end{array}$ & Min. & Max. & N Obs. \\
\hline \#Investments & 7.56 & 3 & 26.56 & 133.54 & 19.14 & 0 & 1107 & 5210 \\
\hline Amount & 5886.74 & 1000 & $34,134.60$ & $18,0791.10$ & $24,356.27$ & $-10,000$ & $1,499,750$ & 5210 \\
\hline Ln(Amount) & 5.98 & 7 & 3.18 & 2.35 & 2.76 & 0 & 14 & 5210 \\
\hline \#Investments $0 \rightarrow t-1$ & 436.85 & 315 & 387.95 & 303.35 & 166.38 & 0 & 1966 & 5210 \\
\hline $\operatorname{Ln}(\text { Amount })_{0 \rightarrow t-1}$ & 11.85 & 12 & 1.88 & 1.85 & 1.41 & 0 & 16 & 5210 \\
\hline Post Funded $=1$ & 0.86 & 1 & 0.35 & 0.27 & 0.23 & 0 & 1 & 5210 \\
\hline Active Campaigns & 6.55 & 7 & 2.36 & 2.20 & 1.43 & 0 & 12 & 5210 \\
\hline Competing Investments & 40.37 & 25 & 67.05 & 17.97 & 64.86 & 0 & 1158 & 5210 \\
\hline Equity Share & 2.36 & 2 & 1.55 & 1.51 & 0.00 & 1 & 8 & 5210 \\
\hline Seedmatch $=1$ & 0.45 & 0 & 0.50 & 0.50 & 0.00 & 0 & 1 & 5210 \\
\hline Update & 0.04 & 0 & 0.21 & 0.09 & 0.20 & 0 & 2 & 5210 \\
\hline Update Number & 0.18 & 0 & 1.00 & 0.32 & 0.98 & 0 & 14 & 5210 \\
\hline Flesch Index & 0.12 & 0 & 0.57 & 0.28 & 0.55 & 0 & 5 & 5210 \\
\hline Words & 12.82 & 0 & 70.42 & 18.19 & 69.09 & 0 & 939 & 5210 \\
\hline Update Categories & & & & & & & Yes & \\
\hline Team $=1$ & 0.01 & 0 & 0.09 & 0.02 & 0.09 & & 41 & 5210 \\
\hline Business Model = 1 & 0.02 & 0 & 0.14 & 0.07 & 0.14 & & 110 & 5210 \\
\hline External Certification $=1$ & 0.02 & 0 & 0.13 & 0.02 & 0.13 & & 91 & 5210 \\
\hline Product Development = 1 & 0.02 & 0 & 0.14 & 0.03 & 0.13 & & 97 & 5210 \\
\hline Cooperation Projects = 1 & 0.01 & 0 & 0.11 & 0.02 & 0.11 & & 67 & 5210 \\
\hline Campaign Development $=1$ & 0.01 & 0 & 0.10 & 0.06 & 0.10 & & 51 & 5210 \\
\hline New Funding = 1 & 0.00 & 0 & 0.05 & 0.01 & 0.05 & & 15 & 5210 \\
\hline Business Development $=1$ & 0.01 & 0 & 0.12 & 0.02 & 0.12 & & 75 & 5210 \\
\hline Promotions $=1$ & 0.02 & 0 & 0.14 & 0.06 & 0.14 & & 102 & 5210 \\
\hline
\end{tabular}

This table shows summary statistics of our main variables. All variables are defined in Table 5 in the Appendix.

effect for our explanatory variables. The evidence shows, however, that updates with an easier language increase crowd participation as measured by the number of investments the following day. No such effect, however, exists for the amount invested. Furthermore, the average ease of the language over the course of the last week did neither affect the number nor the amount of investments, indicating that an easier language attracts more investors right after the update was posted but not over a longer time period. Hence, we only find partial support for H4. Regarding the length of updates, we do not find any statistically significant effect on crowd participation. Hence, H5 is not supported by our results.

In a next step, we investigate RQ3 by analyzing the type of information communicated via updates. In line with our previous findings, none of the different update categories had an immediate effect on crowd participation. However, we find a positive and significant effect for New Funding, with one more update of this category increasing the number of investments by $45 \%$ the following day. Furthermore, Cooperation Projects also has a positive effect on the amount invested by the crowd, leading to a $52 \%$ increase of the amount invested the following day. When analyzing the update activities that took place over the course of 1 week, we find that information about Campaign Developments, New Funding, and Business Development attract additional investors, thereby increasing the number of investments by $17 \%, 51 \%$, and $19 \%$, respectively. When looking at the long-run effects of updates over the course of an entire week, we also find that information about $\mathrm{New}$ 
Table 3 Baseline regressions

\begin{tabular}{|c|c|c|c|c|c|c|}
\hline \multirow[b]{2}{*}{ Variable lag } & \multicolumn{3}{|c|}{ Investments (\#) } & \multicolumn{3}{|c|}{$\operatorname{Ln}($ Amount $(€))$} \\
\hline & $\begin{array}{l}\text { Model } 1 \\
\text { None }\end{array}$ & $\begin{array}{l}\text { Model } 2 \\
1 \text { day }\end{array}$ & $\begin{array}{l}\text { Model } 3 \\
1 \text { week }\end{array}$ & $\begin{array}{l}\text { Model } 4 \\
\text { None }\end{array}$ & $\begin{array}{l}\text { Model } 5 \\
1 \text { day }\end{array}$ & $\begin{array}{l}\text { Model } 6 \\
1 \text { week }\end{array}$ \\
\hline \multicolumn{7}{|l|}{$\begin{array}{l}\text { Control variables } \\
\text { (no lags included) }\end{array}$} \\
\hline $\operatorname{Ln}\left(\right.$ Amount $\left._{0} \rightarrow t-1\right)$ & $\begin{array}{l}1.04 \\
(0.07)\end{array}$ & $\begin{array}{l}1.03 \\
(0.04)\end{array}$ & $\begin{array}{l}1.26 \\
(0.22)\end{array}$ & $\begin{array}{l}0.08 \\
(0.20)\end{array}$ & $\begin{array}{l}0.08 \\
(0.20)\end{array}$ & $\begin{array}{l}-0.86 \\
(0.58)\end{array}$ \\
\hline \#Investments $_{0} \rightarrow t-1 / 100$ & $\begin{array}{l}0.91 * * \\
(0.04)\end{array}$ & $\begin{array}{l}0.91 * * * \\
(0.03)\end{array}$ & $\begin{array}{l}0.92 \\
(0.07)\end{array}$ & $\begin{array}{l}-0.32 * * * \\
(0.08)\end{array}$ & $\begin{array}{l}-0.32 * * * \\
(0.08)\end{array}$ & $\begin{array}{l}-0.22 \\
(0.20)\end{array}$ \\
\hline Post Funded Dummy & $\begin{array}{l}1.05 \\
(0.11)\end{array}$ & $\begin{array}{l}1.06 \\
(0.12)\end{array}$ & $\begin{array}{l}0.99 \\
(0.20)\end{array}$ & $\begin{array}{l}-0.63 * * \\
(0.29)\end{array}$ & $\begin{array}{l}-0.64 * * \\
(0.29)\end{array}$ & $\begin{array}{l}0.59 \\
(0.50)\end{array}$ \\
\hline Active Projects & $\begin{array}{l}1.02 \\
(0.03)\end{array}$ & $\begin{array}{l}1.02 \\
(0.03)\end{array}$ & $\begin{array}{l}1.02 \\
(0.03)\end{array}$ & $\begin{array}{l}-0.05 \\
(0.06)\end{array}$ & $\begin{array}{l}-0.05 \\
(0.06)\end{array}$ & $\begin{array}{l}-0.01 \\
(0.06)\end{array}$ \\
\hline Competing Investments / 100 & $\begin{array}{l}1.08 * * * \\
(0.02)\end{array}$ & $\begin{array}{l}1.08 * * \\
(0.03)\end{array}$ & $\begin{array}{l}1.06 \\
(0.04)\end{array}$ & $\begin{array}{l}0.24 * * * \\
(0.06)\end{array}$ & $\begin{array}{l}0.24 * * * \\
(0.06)\end{array}$ & $\begin{array}{l}0.15 \\
(0.08)\end{array}$ \\
\hline Equity Share & $\begin{array}{l}0.89 \\
(0.07)\end{array}$ & $\begin{array}{l}0.89 \\
(0.08)\end{array}$ & $\begin{array}{l}1.15 \\
(0.13)\end{array}$ & & & \\
\hline Seedmatch Dummy & $\begin{array}{l}0.39 * * * \\
(0.09)\end{array}$ & $\begin{array}{l}0.40 * * * \\
(0.10)\end{array}$ & $\begin{array}{l}0.18^{* * *} \\
(0.16)\end{array}$ & & & \\
\hline \multicolumn{7}{|l|}{$\begin{array}{l}\text { Explanatory variables } \\
\text { (lags according to table head) }\end{array}$} \\
\hline Update & $\begin{array}{l}1.14 \\
(0.15)\end{array}$ & $\begin{array}{l}1.19 * * \\
(0.08)\end{array}$ & $\begin{array}{l}1.16^{* * *} \\
(0.09)\end{array}$ & $\begin{array}{l}0.04 \\
(0.19)\end{array}$ & $\begin{array}{l}0.23 \\
(0.25)\end{array}$ & $\begin{array}{l}0.40 * * \\
(0.19)\end{array}$ \\
\hline Update Number & $\begin{array}{l}1.01 \\
(0.04)\end{array}$ & $\begin{array}{l}1.03 \\
(0.02)\end{array}$ & $\begin{array}{l}0.93 * * \\
(0.03)\end{array}$ & $\begin{array}{l}0.08 \\
(0.04)\end{array}$ & $\begin{array}{l}0.11 \\
(0.05)\end{array}$ & $\begin{array}{l}0.08 \\
(0.13)\end{array}$ \\
\hline \multicolumn{7}{|l|}{ Fixed effects } \\
\hline Campaign & Yes*** & Yes*** & Yes*** & Yes*** & Yes*** & Yes*** \\
\hline Day-of-week & Yes $^{* * *}$ & Yes $^{* * *}$ & Yes $* * *$ & Yes $* * *$ & Yes $* * *$ & Yes $^{* *}$ \\
\hline Month & Yes & Yes & Yes*** & Yes & Yes & Yes $^{* *}$ \\
\hline Year & Yes & Yes & Yes & Yes & Yes*** & Yes** \\
\hline Day-of-funding-cycle & Yes*** & Yes*** & Yes $* * *$ & Yes*** & Yes $* * *$ & Yes*** \\
\hline Log likelihood & $-12,536.57$ & $-12,525.83$ & -2964.41 & & & \\
\hline Adj. $R^{2}$ & & & & 0.14 & 0.14 & 0.08 \\
\hline$N$ Investments days & 5209 & 5209 & 5209 & 5201 & 5201 & 5201 \\
\hline$N$ Campaigns & 70 & 70 & 70 & 71 & 71 & 71 \\
\hline
\end{tabular}

This table shows results of our baseline regressions as specified in Section 3.5. Next to the variables reported in the table, the baseline regressions also include dummy variables for the campaign, day of the week, month of the year, year effects, as well as the first and last 7 days of the campaign. Variable definitions are reported in Table 5. The dependent variable in column (1) is the number of investments and in column (2) the Ln(Amount) of investments in a specific campaign and day. The data takes panel data structure. The method of estimation in column (1) is the negative binomial fixed effects panel estimator (standard errors are bootstrapped) and in column (2) the OLS fixed effects panel estimator (standard errors are clustered on campaign level). Standard errors are reported in brackets

Significance levels for coefficients: $* *<5 \%, * * *<1 \%$

Funding and Business Development both increase the amount of funding on subsequent days by $58 \%$. External Certification, in contrast, has a negative effect on the amount invested, which might arise because updates on external certificates provide a dubious signal to the crowd: these start-ups are unable to obtain funding other than equity crowdfunding even though they have obtained an external certificate such as a patent.

Finally, in Tables 7 and 8 in the Appendix, we investigate RQ2 and RQ3 in more detail by analyzing the effect 
Fig. 3 Predictive margins regarding the effects of updates on crowd participation. The figure reports predictive margins for the number of an update in an equity crowdfunding campaign. It reveals that the first updates have a positive but only marginally significant effect, while the latter updates have no significant effect on crowd participation

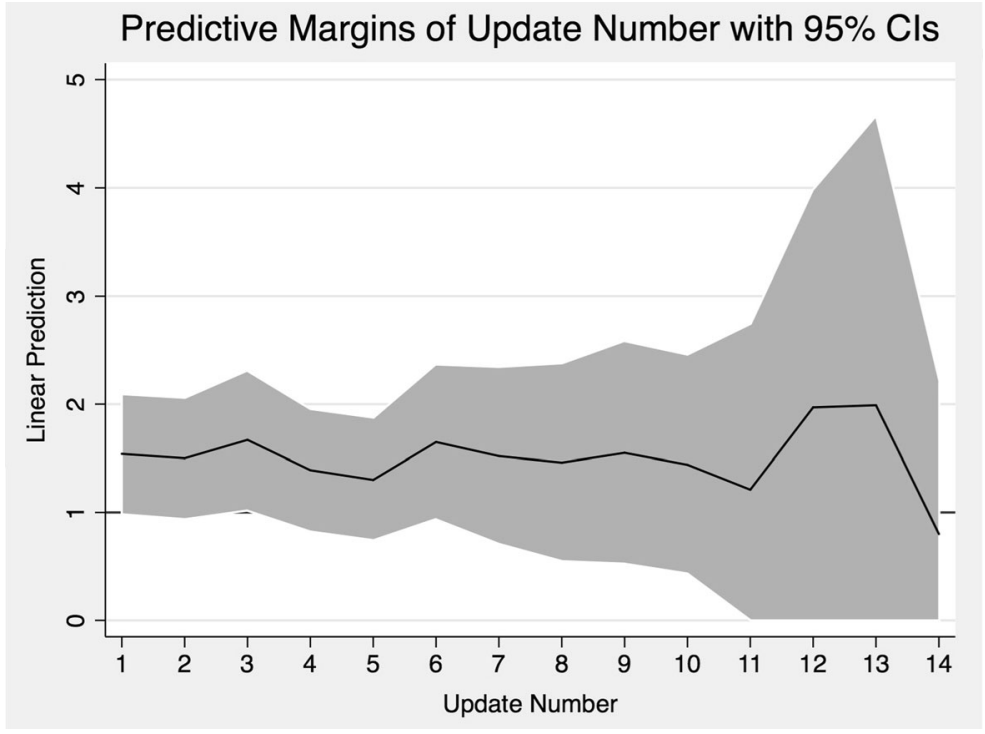

of updates in different industries (communication, wholesale, and retail, as well as manufacturing) and different portals (Companisto and Seedmatch). The results indicate that a simple language is particularly important in crowdfunding campaigns from the manufacturing domain, while the information content of an update appears to be less important there. By contrast, during the course of one week, information about Cooperation Projects, New Funding, Business Development, and Promotional Campaigns had a particularly positive and statistically significant effect in the wholesale and retail industry. Finally, while Cooperation Projects had a positive effect on the amount pledged on Seedmatch, information about Campaign Development and Business Development appeared to be more important for the crowd that invested on Companisto. These results show that start-ups must consider whether a specific information content works for the campaign under consideration and whether the crowd on a particular portal is likely to respond to it.

\section{Discussion, limitations, and further research}

We began with the question whether and to what extent updates posted by start-ups during an equity crowdfunding campaign influence crowd participation. We argued that updates are a tool to signal the start-up's quality to potential investors during a crowdfunding campaign. Based on this main research objective, we further investigated whether the frequency of updates has a positive effect on crowd participation and whether the effect occurs immediately or in a lagged form (RQ1). Our results show that there is indeed a statistically and economically significant effect of updates on crowd participation. Posting an update increases both the number of investments by the crowd and the investment amount collected. However, this effect does not occur immediately in its entirety; rather, it lags behind the update by a few days. In addition, our findings suggest that even though investors value signals provided by start-ups, an increasing number of updates seem to result in a loss of credibility and might even be perceived as cheap talk as additional updates no longer have a statistically significant effect on crowd participation.

Furthermore, we argued that the clarity of updates is important for crowd participation (RQ2). We measured the clarity of updates in terms of language complexity and update length. We find that the clarity of updates does not seem to be of particular relevance to the crowd. Even though our findings suggest that an easier readability has a positive effect on crowd participation the day after the update was posted, this effect is lost after a few days. This result suggests that crowd investors do not seem particularly concerned about language complexity. However, the readability of most updates was relatively homogenous with a Flesch index between 40 and 65 (categories 2-4) targeting readers with a good or very good education (Courtis 1995). Only a small number of updates had a readability index in the category "very difficult" and none in the categories "easy" and "very easy." This result might be due to a good education of crowd investors and the entrepreneur posting 
Table 4 Effects of update categories on crowd participation

\begin{tabular}{|c|c|c|c|c|c|c|}
\hline \multirow[b]{2}{*}{ Variable lag } & \multicolumn{3}{|c|}{ Investments (\#) } & \multicolumn{3}{|c|}{ Ln(Amount $(€))$} \\
\hline & $\begin{array}{l}\text { Model } 1 \\
\text { None }\end{array}$ & $\begin{array}{l}\text { Model } 2 \\
1 \text { day }\end{array}$ & $\begin{array}{l}\text { Model } 3 \\
1 \text { week }\end{array}$ & $\begin{array}{l}\text { Model } 4 \\
\text { None }\end{array}$ & $\begin{array}{l}\text { Model } 5 \\
1 \text { day }\end{array}$ & $\begin{array}{l}\text { Model } 6 \\
1 \text { week }\end{array}$ \\
\hline \multicolumn{7}{|l|}{$\begin{array}{l}\text { Explanatory variables } \\
\text { (lags according to table head) }\end{array}$} \\
\hline Flesch Index & $\begin{array}{l}1.02 \\
(0.04)\end{array}$ & $\begin{array}{l}1.07 * * \\
(0.03)\end{array}$ & $\begin{array}{l}1.00 \\
(0.00)\end{array}$ & $\begin{array}{l}0.11 \\
(0.08)\end{array}$ & $\begin{array}{l}0.04 \\
(0.09)\end{array}$ & $\begin{array}{l}0.01 \\
(0.00)\end{array}$ \\
\hline Words / 100 & $\begin{array}{l}1.00 \\
(0.02)\end{array}$ & $\begin{array}{l}0.99 \\
(0.03)\end{array}$ & $\begin{array}{l}0.97 \\
(0.02)\end{array}$ & $\begin{array}{l}0.09 \\
(0.06)\end{array}$ & $\begin{array}{l}0.06 \\
(0.09)\end{array}$ & $\begin{array}{l}0.03 \\
(0.06)\end{array}$ \\
\hline Team & $\begin{array}{l}1.05 \\
(0.16)\end{array}$ & $\begin{array}{l}0.87 \\
(0.09)\end{array}$ & $\begin{array}{l}1.08 \\
(0.14)\end{array}$ & $\begin{array}{l}-0.26 \\
(0.31)\end{array}$ & $\begin{array}{l}-0.33 \\
(0.34)\end{array}$ & $\begin{array}{l}0.22 \\
(0.21)\end{array}$ \\
\hline Business Model & $\begin{array}{l}1.10 \\
(0.15)\end{array}$ & $\begin{array}{l}0.92 \\
(0.12)\end{array}$ & $\begin{array}{l}0.91 \\
(0.06)\end{array}$ & $\begin{array}{l}-0.50 \\
(0.28)\end{array}$ & $\begin{array}{l}-0.21 \\
(0.32)\end{array}$ & $\begin{array}{l}-0.04 \\
(0.22)\end{array}$ \\
\hline External Certification & $\begin{array}{l}0.87 \\
(0.13)\end{array}$ & $\begin{array}{l}1.10 \\
(0.18)\end{array}$ & $\begin{array}{l}1.11 \\
(0.10)\end{array}$ & $\begin{array}{l}-0.19 \\
(0.22)\end{array}$ & $\begin{array}{l}-0.43 \\
(0.33)\end{array}$ & $\begin{array}{l}-0.54 * * \\
(0.24)\end{array}$ \\
\hline Product Development & $\begin{array}{l}0.92 \\
(0.08)\end{array}$ & $\begin{array}{l}0.99 \\
(0.10)\end{array}$ & $\begin{array}{l}1.06 \\
(0.07)\end{array}$ & $\begin{array}{l}0.17 \\
(0.28)\end{array}$ & $\begin{array}{l}0.14 \\
(0.26)\end{array}$ & $\begin{array}{l}0.07 \\
(0.15)\end{array}$ \\
\hline Cooperation Projects & $\begin{array}{l}1.16 \\
(0.10)\end{array}$ & $\begin{array}{l}1.07 \\
(0.08)\end{array}$ & $\begin{array}{l}0.97 \\
(0.09)\end{array}$ & $\begin{array}{l}0.13 \\
(0.23)\end{array}$ & $\begin{array}{l}0.52 * * \\
(0.23)\end{array}$ & $\begin{array}{l}0.27 \\
(0.20)\end{array}$ \\
\hline Campaign Development & $\begin{array}{l}1.15 \\
(0.14)\end{array}$ & $\begin{array}{l}1.21 \\
(0.19)\end{array}$ & $\begin{array}{l}1.17 * * \\
(0.08)\end{array}$ & $\begin{array}{l}-0.13 \\
(0.30)\end{array}$ & $\begin{array}{l}0.55 \\
(0.31)\end{array}$ & $\begin{array}{l}0.24 \\
(0.18)\end{array}$ \\
\hline New Funding & $\begin{array}{l}0.76 \\
(0.21)\end{array}$ & $\begin{array}{l}1.45^{* *} \\
(0.25)\end{array}$ & $\begin{array}{l}1.51 * * * \\
(0.24)\end{array}$ & $\begin{array}{l}0.36 \\
(0.66)\end{array}$ & $\begin{array}{l}0.74 \\
(0.37)\end{array}$ & $\begin{array}{l}0.58 * * \\
(0.29)\end{array}$ \\
\hline Business Development & $\begin{array}{l}1.21 \\
(0.15)\end{array}$ & $\begin{array}{l}1.15 \\
(0.14)\end{array}$ & $\begin{array}{l}1.19 * * \\
(0.11)\end{array}$ & $\begin{array}{l}-0.05 \\
(0.24)\end{array}$ & $\begin{array}{l}0.51 \\
(0.27)\end{array}$ & $\begin{array}{l}0.58 * * \\
(0.23)\end{array}$ \\
\hline Promotions & $\begin{array}{l}1.13 \\
(0.11)\end{array}$ & $\begin{array}{l}0.99 \\
(0.11)\end{array}$ & $\begin{array}{l}1.10 \\
(0.06)\end{array}$ & $\begin{array}{l}0.17 \\
(0.26)\end{array}$ & $\begin{array}{l}0.21 \\
(0.27)\end{array}$ & $\begin{array}{l}0.24 \\
(0.17)\end{array}$ \\
\hline Baseline and fixed effects & Yes*** & Yes $^{* * *}$ & Yes*** & Yes*** & Yes*** & Yes*** \\
\hline Log likelihood & $-12,524.40$ & $-12,519.53$ & $-12,475.50$ & & & \\
\hline Adj. $R^{2}$ & & & & 0.14 & 0.14 & 0.15 \\
\hline$N$ Investments days & 5209 & 5209 & 5209 & 5201 & 5201 & 5201 \\
\hline$N$ Campaigns & 70 & 70 & 70 & 71 & 71 & 71 \\
\hline
\end{tabular}

This table shows results of our baseline regressions as specified in Section 3.5 as well as additional variables. The results of the baseline regression remain largely unchanged and are therefore not reported again. Next to the variables reported in the table, the regressions also include dummy variables for the campaign, day of the week, month of the year, year effects, as well as the first and last 7 days of the campaign. Variable definitions are reported in Table 5 in the appendix. The dependent variable in columns (1) to (3) is the number of investments and in columns (4) to (6) the Ln(Amount) of investments in a specific campaign and day. The data takes panel data structure. The method of estimation in columns (1) to (3) is the negative binomial fixed effects panel estimator (standard errors are bootstrapped) and in columns (4) to (6) the OLS fixed effects panel estimator (standard errors are clustered on campaign level). Standard errors are reported in brackets

Significance levels for coefficients: $* *<5 \%, * * *<1 \%$

the update as well as the expectation of the crowd that startups communicate in a more sophisticated way to demonstrate their preparedness to establish and run a successful company (Mollick 2014; Ahlers et al. 2015).
While recent research shows that entrepreneurs strategically engage in update communication (Dorfleitner et al. 2017), our results reveal that the type of information provided in the update plays an important role for equity 
crowdfunding participation. Updates that inform the crowd about new funding and business developments seem to be valued highly by investors. Updates providing information about campaign developments and cooperation projects also have a positive effect on crowd participation. In contrast to previous findings, investors did not seem to value information about the start-up team (Ahlers et al. 2015; Moritz et al. 2015; Bernstein et al. 2017). This result might be explained by the fact that the start-up team typically does not change during a crowdfunding campaign and that investors expect to receive information about consistent factors of the start-up directly at the beginning of the campaign, e.g., in the business plan. This interpretation is supported by the results regarding the business model. Altogether, our results suggest that investors seem to value updates signaling additional and dynamic aspects about the start-up's quality during a crowdfunding campaign and do not value information which should have been provided at the funding start. The negative effect of external certifications on crowd investments is rather surprising and indicates that the crowd does not find expert opinions, success stories, awards received, and patents obtained credible and valuable. However, a deeper analysis of this category with a larger data set is required to better understand the crowds' reaction to this information.

Our paper contributes to the entrepreneurial finance and crowdfunding literatures. We contribute to research on the selection criteria of early-stage investors. It has been found that start-ups use specific information such as the quality of their management, intellectual property, the venture's network, and firm alliances to signal their quality to investors (Audretsch et al. 2012; Baum and Silverman 2004; Block et al. 2014; Franke et al. 2008; Jell et al. 2011). In our analysis, we have shown that specific signals in crowdfunding campaigns also seem to enhance the likelihood of a successful campaign. Hence, our paper expands research on signaling theory by analyzing effective signals within updates during equity crowdfunding campaigns. In addition, our paper contributes to the small but growing literature on the effects of information disclosure on equity crowdfunding participation (Vismara 2016b; Ahlers et al. 2015; Moritz et al. 2015; Moritz and Block 2015; Bernstein et al. 2017). So far, this literature has not taken into account that start-ups can also provide or disclose information to the crowd while running an equity crowdfunding campaign. Our analysis takes a dynamic approach to this issue and investigates these disclosure effects, considering updates that are given during ongoing crowdfunding campaigns.
This paper is not without limitations, which provide fruitful avenues for further research. Although we consider two different portals, the sample size of 71 funding campaigns and 39,399 investment decisions is still relatively small. Our dataset is slightly biased. Extremely positive crowdfunding campaigns, where the funding limit was reached within a few hours, simply had no time (or need) to publish updates. The sample size does not allow us to build larger subgroups of start-ups from different industries, countries, and development stages. Future research could collect larger samples of funding campaigns and investigate potential moderation effects related to start-up or campaign characteristics. We would expect, for example, to see stronger positive effects of updates on patents and successful prototypes in technology-intensive industries than in other industries. Our subsample of start-ups in technology-intensive industries is too small to investigate such moderation effects. Moreover, with a larger sample of start-ups and campaigns, one could compare lone founder start-ups with team start-ups. It might very well be that updates on new team members have particularly meaningful effects for lone founder start-ups, especially when the founder lacks technological and/or business competences. Another possible avenue for further research is to extend the research about the effects of updates on crowd participation to reward-based crowdfunding (Colombo et al. 2015; Mollick 2014; Xu et al. 2014). Mollick (2014), for example, has shown that projects with updates are more likely than other projects to attract funding from the crowd. However, he does not distinguish between different types of updates. Given the particularities of reward-based crowdfunding and its strong focus on products and projects, we would expect updates with information about project and product developments to have particularly strong effects.

\section{Implications for practice}

Our paper's results are important for start-ups seeking equity crowdfunding. Knowing which updates drive funding participation is crucial for start-ups when designing an effective and successful investor communication and social media strategy for their equity crowdfunding campaigns. By posting updates, start-ups can actively influence their campaigns' chances of success. The crowd seems particularly sensitive to verifiable and business-related information about the development of the start-up 
since funding start such as new fundings and business developments, whereas information about the underlying business model, team, and promotional activities does not provide much additional value. In this sense, the crowd seems to behave like professional investors who focus on verifiable, businessrelated, and cash-flow relevant additional information as decision criteria for their investments (Boocock and Woods 1997). This information is also important for crowdfunding platforms. By encouraging start-ups to publish specific types of updates that can increase the likelihood of successful crowdfunding campaigns, the platforms' own business success will be improved.

Acknowledgments Open access funding was provided by the Max Planck Society. This article evolved as part of the research project "Crowdinvesting in Germany, England and the USA: Regulatory Perspectives and Welfare Implications of a New Financing Scheme", which was supported by the German Research Foundation (Deutsche Forschungsgemeinschaft) under the grant number HO 5296/1-1. The authors thank Silvio Vismara, and the participants of the 20th G-Forum (Handelshochschule Leipzig) and the 4th Crowdinvesting Symposium (Max Planck Institute for Innovation and Competition). Gerrit Engelmann provided excellent research assistance. All errors are our own.

\section{Appendix}

Table 5 Definitions of variables

Dependent variables:

Ln(Amount): The natural logarithm of the amount of money in EUR invested by crowd investors on day $t$ in campaign $i$.

\#Investments: The number of investments made by crowd investors on day $t$ in campaign $i$.

Control variables:

$\operatorname{Ln}\left(\right.$ Amount $\left._{0 \rightarrow t-1}\right)$ : The natural logarithm of the total amount of money in EUR invested by the crowd until the previous day in campaign $i$.

\#Investments ${ }_{0 \rightarrow t-1}$ : The total number of investments made by the crowd until the previous day in a particular campaign.

Post Funded: Dummy variable equal to 1 if the campaign has surpassed the Funding Goal, and 0 otherwise.

Active Campaigns: The total number of campaigns across three major and one minor German equity crowdfunding portal (Seedmatch, Companisto, Innovestment, and United Equity) accepting investments on day $t$.

Competing Investments: The total number of investments made on day $t$ across all campaigns ran on three major and one minor German equity crowdfunding portal (Seedmatch, Companisto, Innovestment, and United Equity) that where not attracted by campaign $i$.

Equity Share: Is the amount of capital requested by the venture (funding goal) over its pre-money valuation.

Seedmatch: Dummy variable equal to 1 if the campaign was run on Seedmatch, and 0 if it was run on Companisto.

Explanatory variables-RQ1:

Update: The number of updates posted on the portal website by the start-up on day $t$ in campaign $i$.

Update Number: Is the number of an update during the campaign. At a maximum, the campaign MyParfum on Companisto counted 14 updates. For the lagged variables, we use the average of previous updates' number.

Explanatory variables-RQ2:

Flesch Index: Is the Flesch Readability Index, using a categorization with a seven item scale (Courtis 1995), where 1 corresponds to a Flesch index of 0-30 "very difficult language," 2 to 31-50 "difficult," 3 to 51-60 "fairly difficult," 4 to 61-70 "standard," 5 to 71-80 "fairly easy," 6 to 81-90 “easy," and 7 to 91-100 "very easy language." For the lagged variables, we use the average of previous updates' Flesch index.

Words: Is the total number of words that appeared in the update text. For the lagged variables, we use the average of previous updates' word count.

Explanatory variables-RQ3:

Team: Dummy variable equal to 1 if the update contained information about the entrepreneurial team (education, previous work experience), and 0 otherwise. 
Table 5 (continued)

Business Model: Dummy variable equal to 1 if the update contained a description of the business model, the relevant market, or future business orientation, and 0 otherwise.

External Certification: Dummy variable equal to 1 if the update contained an expert opinion, success stories, news about awards received, patent applications, patent approvals as well as press and media coverages about the start-up, and 0 otherwise.

Product Development: Dummy variable equal to 1 if the update contained information about the product, target costumers, prototypes, or new product inventions, and 0 otherwise.

Cooperation Projects: Dummy variable equal to 1 if the update contained information about new collaborations $t$ he start-up engaged in, and 0 otherwise.

Campaign Development: Dummy variable equal to 1 if the update contained information about campaign updates (number of crowd investors, achieved funding amount) or announcements that the funding limit has been changed, and 0 otherwise.

New Funding: Dummy variable equal to 1 if the update contained information of whether the start-up received additional funding from business angels, venture capitalists or government grants, and 0 otherwise.

Business Development: Dummy variable equal to 1 if the update contained information about the financial development of the start-up and its customer base (e.g., number of customers, new customers), and 0 otherwise.

Promotions: Dummy variable equal to 1 if the update contained information about promotions the crowd may receive (discounts, perks), open calls to participate via social media, invitations for personal meetings (open house events) and appeals to investors to support the start-up (marketing, recommendations, network), and 0 otherwise.

Table 6 Correlation matrix: update categories

\begin{tabular}{|c|c|c|c|c|c|c|c|c|c|c|c|c|c|}
\hline & & [1] & {$[2]$} & [3] & {$[4]$} & {$[5]$} & {$[6]$} & [7] & [8] & [9] & {$[10]$} & {$[11]$} & {$[12]$} \\
\hline Investments (\# per day) & {$[1]$} & & & & & & & & & & & & \\
\hline Ln(Amount in $€)$ & {$[2]$} & 0.31 & & & & & & & & & & & \\
\hline Team & {$[3]$} & 0.16 & 0.05 & & & & & & & & & & \\
\hline Business Model & {$[4]$} & 0.13 & 0.04 & 0.43 & & & & & & & & & \\
\hline External Certification & {$[5]$} & 0.03 & 0.04 & 0.17 & 0.47 & & & & & & & & \\
\hline Product Development & {$[6]$} & 0.12 & 0.05 & 0.33 & 0.53 & 0.34 & & & & & & & \\
\hline Cooperation Projects & [7] & 0.03 & 0.02 & 0.24 & 0.55 & 0.45 & 0.36 & & & & & & \\
\hline Campaign Development & {$[8]$} & 0.07 & 0.05 & 0.06 & 0.23 & 0.24 & 0.20 & 0.16 & & & & & \\
\hline New Funding & {$[9]$} & 0.01 & 0.02 & 0.12 & 0.14 & 0.32 & 0.05 & 0.15 & 0.07 & & & & \\
\hline Business Development & {$[10]$} & 0.06 & 0.03 & 0.23 & 0.47 & 0.50 & 0.32 & 0.42 & 0.20 & 0.18 & & & \\
\hline Promotions & {$[11]$} & 0.08 & 0.05 & 0.33 & 0.41 & 0.38 & 0.41 & 0.30 & 0.34 & 0.12 & 0.25 & & \\
\hline Words & {$[12]$} & 0.11 & 0.06 & 0.45 & 0.72 & 0.66 & 0.54 & 0.54 & 0.37 & 0.26 & 0.53 & 0.64 & \\
\hline Flesch Index & [13] & 0.14 & 0.08 & 0.41 & 0.63 & 0.56 & 0.60 & 0.46 & 0.49 & 0.18 & 0.49 & 0.64 & 0.79 \\
\hline
\end{tabular}


Table 7 Effects of update categories by industry sector

Panel A: Manufacturing

\begin{tabular}{|c|c|c|c|c|c|c|}
\hline \multirow[b]{2}{*}{$\begin{array}{l}\text { Variable lag } \\
\text { Explanatory variables } \\
\text { (lags according to table head) }\end{array}$} & \multicolumn{3}{|c|}{ Investments (\# per day) } & \multicolumn{3}{|c|}{ Ln(Amount in $€)$} \\
\hline & $\begin{array}{l}\text { Model } 1 \\
\text { None }\end{array}$ & $\begin{array}{l}\text { Model } 2 \\
1 \text { day }\end{array}$ & $\begin{array}{l}\text { Model } 3 \\
1 \text { week }\end{array}$ & $\begin{array}{l}\text { Model } 4 \\
\text { None }\end{array}$ & $\begin{array}{l}\text { Model } 5 \\
1 \text { day }\end{array}$ & $\begin{array}{l}\text { Model } 6 \\
1 \text { week }\end{array}$ \\
\hline Flesch Index & $\begin{array}{l}0.88 \\
(0.08)\end{array}$ & $\begin{array}{l}1.12 * * * \\
(0.05)\end{array}$ & $\begin{array}{l}1.00 \\
(0.00)\end{array}$ & $\begin{array}{l}-0.12 \\
(0.12)\end{array}$ & $\begin{array}{l}0.08 \\
(0.16)\end{array}$ & $\begin{array}{l}0.01 \\
(0.01)\end{array}$ \\
\hline Words / 100 & $\begin{array}{l}0.95 \\
(0.14)\end{array}$ & $\begin{array}{l}1.07 \\
(0.21)\end{array}$ & $\begin{array}{l}1.04 \\
(0.07)\end{array}$ & $\begin{array}{l}0.11 \\
(0.19)\end{array}$ & $\begin{array}{l}0.17 \\
(0.27)\end{array}$ & $\begin{array}{l}0.03 \\
(0.12)\end{array}$ \\
\hline Team & $\begin{array}{l}1.06 \\
(0.27)\end{array}$ & $\begin{array}{l}0.62 * * * \\
(0.09)\end{array}$ & $\begin{array}{l}1.25 \\
(0.19)\end{array}$ & $\begin{array}{l}-1.65^{*} \\
(0.92)\end{array}$ & $\begin{array}{l}-1.34^{*} \\
(0.74)\end{array}$ & $\begin{array}{l}0.38 \\
(0.34)\end{array}$ \\
\hline Business Model & $\begin{array}{l}0.88 \\
(0.25)\end{array}$ & $\begin{array}{l}0.90 \\
(0.30)\end{array}$ & $\begin{array}{l}1.02 \\
(0.28)\end{array}$ & $\begin{array}{l}0.16 \\
(0.77)\end{array}$ & $\begin{array}{l}-0.45 \\
(0.52)\end{array}$ & $\begin{array}{l}0.26 \\
(0.50)\end{array}$ \\
\hline External Certification & $\begin{array}{l}2.01 * \\
(0.74)\end{array}$ & $\begin{array}{l}0.90 \\
(0.25)\end{array}$ & $\begin{array}{l}1.23 \\
(0.43)\end{array}$ & $\begin{array}{l}-0.11 \\
(0.80)\end{array}$ & $\begin{array}{l}-0.72 \\
(0.56)\end{array}$ & $\begin{array}{l}-0.16 \\
(0.56)\end{array}$ \\
\hline Product Development & $\begin{array}{l}0.90 \\
(0.24)\end{array}$ & $\begin{array}{l}0.86 \\
(0.57)\end{array}$ & $\begin{array}{l}1.03 \\
(0.11)\end{array}$ & $\begin{array}{l}0.98 * * \\
(0.40)\end{array}$ & $\begin{array}{l}0.71 \\
(0.45)\end{array}$ & $\begin{array}{l}-0.17 \\
(0.22)\end{array}$ \\
\hline Cooperation Projects & $\begin{array}{l}1.53 \\
(0.45)\end{array}$ & $\begin{array}{l}1.48 \\
(0.39)\end{array}$ & $\begin{array}{l}0.91 \\
(0.11)\end{array}$ & $\begin{array}{l}0.89 \\
(0.72)\end{array}$ & $\begin{array}{l}0.58 \\
(0.38)\end{array}$ & $\begin{array}{l}0.17 \\
(0.21)\end{array}$ \\
\hline Campaign Development & $\begin{array}{l}1.39 \\
(0.51)\end{array}$ & $\begin{array}{l}1.05 \\
(0.92)\end{array}$ & $\begin{array}{l}0.95 \\
(0.24)\end{array}$ & $\begin{array}{l}-0.76 \\
(0.96)\end{array}$ & $\begin{array}{l}0.18 \\
(0.61)\end{array}$ & $\begin{array}{l}-0.12 \\
(0.53)\end{array}$ \\
\hline New Funding & $\begin{array}{l}0.58 \\
(4.65)\end{array}$ & $\begin{array}{l}0.38 \\
(0.44)\end{array}$ & $\begin{array}{l}0.68 \\
(0.19)\end{array}$ & $\begin{array}{l}-0.95 \\
(1.76)\end{array}$ & $\begin{array}{l}0.07 \\
(0.50)\end{array}$ & $\begin{array}{l}0.46 \\
(0.56)\end{array}$ \\
\hline Business Development & $\begin{array}{l}1.03 \\
(0.35)\end{array}$ & $\begin{array}{l}1.19 \\
(0.47)\end{array}$ & $\begin{array}{l}0.96 \\
(0.11)\end{array}$ & $\begin{array}{l}-1.35^{* *} \\
(0.60)\end{array}$ & $\begin{array}{l}0.20 \\
(0.73)\end{array}$ & $\begin{array}{l}-0.02 \\
(0.23)\end{array}$ \\
\hline Promotions & $\begin{array}{l}1.37 \\
(0.55)\end{array}$ & $\begin{array}{l}0.73 \\
(0.37)\end{array}$ & $\begin{array}{l}1.05 \\
(0.09)\end{array}$ & $\begin{array}{l}0.26 \\
(0.59)\end{array}$ & $\begin{array}{l}0.15 \\
(0.23)\end{array}$ & $\begin{array}{l}-0.08 \\
(0.18)\end{array}$ \\
\hline Baseline and fixed effects & Yes*** & Yes*** & Yes*** & Yes*** & Yes*** & Yes*** \\
\hline Log likelihood & $-12,530.29$ & $-12,528.07$ & $-12,515.02$ & & & \\
\hline Adj. $R^{2}$ & & & & 0.14 & 0.14 & 0.14 \\
\hline$N$ Investments days & 5209 & 5209 & 5209 & 5201 & 5201 & 5201 \\
\hline$N$ Campaigns & 70 & 70 & 70 & 71 & 71 & 71 \\
\hline
\end{tabular}

Panel B: Wholesale and retail

\begin{tabular}{|c|c|c|c|c|c|c|}
\hline \multirow[b]{2}{*}{$\begin{array}{l}\text { Variable lag } \\
\text { Explanatory variables } \\
\text { (lags according to table head) }\end{array}$} & \multicolumn{3}{|c|}{ Investments (\# per day) } & \multicolumn{3}{|c|}{ Ln(Amount in $€)$} \\
\hline & $\begin{array}{l}\text { Model } 1 \\
\text { None }\end{array}$ & $\begin{array}{l}\text { Model } 2 \\
1 \text { day }\end{array}$ & $\begin{array}{l}\text { Model } 3 \\
1 \text { week }\end{array}$ & $\begin{array}{l}\text { Model } 4 \\
\text { None }\end{array}$ & $\begin{array}{l}\text { Model } 5 \\
1 \text { day }\end{array}$ & $\begin{array}{l}\text { Model } 6 \\
1 \text { week }\end{array}$ \\
\hline Flesch Index & $\begin{array}{l}1.17 \\
(0.12)\end{array}$ & $\begin{array}{l}0.96 \\
(0.15)\end{array}$ & $\begin{array}{l}0.99 \\
(0.00)\end{array}$ & $\begin{array}{l}0.31 * \\
(0.16)\end{array}$ & $\begin{array}{l}-0.47 * \\
(0.24)\end{array}$ & $\begin{array}{l}-0.01 \\
(0.01)\end{array}$ \\
\hline Words / 100 & $\begin{array}{l}0.97 \\
(0.07)\end{array}$ & $\begin{array}{l}1.00 \\
(0.11)\end{array}$ & $\begin{array}{l}0.98 \\
(0.04)\end{array}$ & $\begin{array}{l}0.14 \\
(0.15)\end{array}$ & $\begin{array}{l}0.36^{*} \\
(0.19)\end{array}$ & $\begin{array}{l}0.14 \\
(0.15)\end{array}$ \\
\hline Team & $0.61 *$ & 0.96 & 1.03 & $-0.98 * *$ & -0.34 & 0.13 \\
\hline
\end{tabular}


Table 7 (continued)

Panel B: Wholesale and retail

\begin{tabular}{|c|c|c|c|c|c|c|}
\hline \multirow[b]{2}{*}{ Variable lag } & \multicolumn{3}{|c|}{ Investments (\# per day) } & \multicolumn{3}{|c|}{ Ln(Amount in $€)$} \\
\hline & $\begin{array}{l}\text { Model } 1 \\
\text { None } \\
(0.17)\end{array}$ & $\begin{array}{l}\text { Model } 2 \\
1 \text { day } \\
(0.57)\end{array}$ & $\begin{array}{l}\text { Model } 3 \\
1 \text { week } \\
(0.16)\end{array}$ & $\begin{array}{l}\text { Model } 4 \\
\text { None } \\
(0.41)\end{array}$ & $\begin{array}{l}\text { Model } 5 \\
1 \text { day } \\
(0.72)\end{array}$ & $\begin{array}{l}\text { Model } 6 \\
1 \text { week } \\
(0.74)\end{array}$ \\
\hline Business Model & $\begin{array}{l}2.00 * * * \\
(0.49)\end{array}$ & $\begin{array}{l}1.45 \\
(0.98)\end{array}$ & $\begin{array}{l}0.65^{* * * *} \\
(0.09)\end{array}$ & $\begin{array}{l}0.26 \\
(0.65)\end{array}$ & $\begin{array}{l}0.05 \\
(1.01)\end{array}$ & $\begin{array}{l}-1.36^{* * *} \\
(0.55)\end{array}$ \\
\hline External Certification & $\begin{array}{l}2.01 \\
(0.88)\end{array}$ & $\begin{array}{l}0.85 \\
(2.82)\end{array}$ & $\begin{array}{l}0.90 \\
(0.12)\end{array}$ & $\begin{array}{l}0.71 \\
(0.50)\end{array}$ & $\begin{array}{l}-1.71 * * \\
(0.81)\end{array}$ & $\begin{array}{l}-1.48^{* * *} \\
(0.56)\end{array}$ \\
\hline Product Development & $\begin{array}{l}0.57 * \\
(0.19)\end{array}$ & $\begin{array}{l}0.89 \\
(0.36)\end{array}$ & $\begin{array}{l}1.02 \\
(0.11)\end{array}$ & $\begin{array}{l}-0.95 \\
(0.78)\end{array}$ & $\begin{array}{l}-0.31 \\
(0.69)\end{array}$ & $\begin{array}{l}0.25 \\
(0.47)\end{array}$ \\
\hline Cooperation Projects & $\begin{array}{l}0.71 \\
(0.22)\end{array}$ & $\begin{array}{l}1.29 \\
(0.50)\end{array}$ & $\begin{array}{l}1.72 * * * \\
(0.23)\end{array}$ & $\begin{array}{l}-0.23 \\
(0.59)\end{array}$ & $\begin{array}{l}1.64 * * * \\
(0.50)\end{array}$ & $\begin{array}{l}1.86 * * * \\
(0.42)\end{array}$ \\
\hline Campaign Development & $\begin{array}{l}1.19 \\
(0.21)\end{array}$ & $\begin{array}{l}1.72 \\
(0.62)\end{array}$ & $\begin{array}{l}1.17 \\
(0.13)\end{array}$ & $\begin{array}{l}0.58 \\
(0.81)\end{array}$ & $\begin{array}{l}1.65^{* * *} \\
(0.59)\end{array}$ & $\begin{array}{l}0.46 \\
(0.38)\end{array}$ \\
\hline New Funding & $\begin{array}{l}0.58 \\
(0.29)\end{array}$ & $\begin{array}{l}2.26 \\
(7.43)\end{array}$ & $\begin{array}{l}2.30 * * * \\
(0.55)\end{array}$ & $\begin{array}{l}1.27 \\
(0.81)\end{array}$ & $\begin{array}{l}2.81 * * * \\
(0.62)\end{array}$ & $\begin{array}{l}1.74 * * \\
(0.74)\end{array}$ \\
\hline Business Development & $\begin{array}{l}0.86 \\
(0.26)\end{array}$ & $\begin{array}{l}0.88 \\
(0.65)\end{array}$ & $\begin{array}{l}1.61 * * * \\
(0.18)\end{array}$ & $\begin{array}{l}-0.69 \\
(0.75)\end{array}$ & $\begin{array}{l}0.63 \\
(0.68)\end{array}$ & $\begin{array}{l}1.71 * * * \\
(0.56)\end{array}$ \\
\hline Promotions & $\begin{array}{l}1.10 \\
(0.40)\end{array}$ & $\begin{array}{l}1.04 \\
(0.53)\end{array}$ & $\begin{array}{l}1.51 * * * \\
(0.15)\end{array}$ & $\begin{array}{l}0.11 \\
(0.60)\end{array}$ & $\begin{array}{l}0.96^{*} \\
(0.57)\end{array}$ & $\begin{array}{l}1.22 * * \\
(0.48)\end{array}$ \\
\hline $\begin{array}{l}\text { Baseline and fixed effects } \\
\text { Log likelihood }\end{array}$ & $\begin{array}{l}\text { Yes*** } \\
-12,523.85\end{array}$ & $\begin{array}{l}\text { Yes**** } \\
-12,538.39\end{array}$ & $\begin{array}{l}\text { Yes*** } \\
-12,515.93\end{array}$ & Yes*** & Yes*** & Yes*** \\
\hline Adj. $R^{2}$ & & & & 0.14 & 0.14 & 0.15 \\
\hline$N$ Investments days & 5209 & 5209 & 5209 & 5201 & 5201 & 5201 \\
\hline$N$ Campaigns & 70 & 70 & 70 & 71 & 71 & 71 \\
\hline
\end{tabular}

Panel C: Information and communication

\begin{tabular}{|c|c|c|c|c|c|c|}
\hline \multirow[b]{2}{*}{$\begin{array}{l}\text { Variable lag } \\
\text { Explanatory variables } \\
\text { (lags according to table head) }\end{array}$} & \multicolumn{3}{|c|}{ Investments (\# per day) } & \multicolumn{3}{|c|}{$\operatorname{Ln}($ Amount in $€)$} \\
\hline & $\begin{array}{l}\text { Model } 1 \\
\text { None }\end{array}$ & $\begin{array}{l}\text { Model } 2 \\
1 \text { day }\end{array}$ & $\begin{array}{l}\text { Model } 3 \\
1 \text { week }\end{array}$ & $\begin{array}{l}\text { Model } 4 \\
\text { None }\end{array}$ & $\begin{array}{l}\text { Model } 5 \\
1 \text { day }\end{array}$ & $\begin{array}{l}\text { Model } 6 \\
1 \text { week }\end{array}$ \\
\hline Flesch Index & $\begin{array}{l}1.01 \\
(0.06)\end{array}$ & $\begin{array}{l}1.09 \\
(0.06)\end{array}$ & $\begin{array}{l}1.00 \\
(0.00)\end{array}$ & $\begin{array}{l}0.10 \\
(0.14)\end{array}$ & $\begin{array}{l}0.18 \\
(0.20)\end{array}$ & $\begin{array}{l}0.00 \\
(0.00)\end{array}$ \\
\hline Words / 100 & $\begin{array}{l}1.00 \\
(0.06)\end{array}$ & $\begin{array}{l}0.98 \\
(0.04)\end{array}$ & $\begin{array}{l}0.99 \\
(0.03)\end{array}$ & $\begin{array}{l}0.06 \\
(0.11)\end{array}$ & $\begin{array}{l}-0.08 \\
(0.14)\end{array}$ & $\begin{array}{l}0.02 \\
(0.08)\end{array}$ \\
\hline Team & $\begin{array}{l}1.59 * * \\
(0.31)\end{array}$ & $\begin{array}{l}1.09 \\
(0.21)\end{array}$ & $\begin{array}{l}1.11 \\
(0.16)\end{array}$ & $\begin{array}{l}0.12 \\
(0.46)\end{array}$ & $\begin{array}{l}0.29 \\
(0.55)\end{array}$ & $\begin{array}{l}0.03 \\
(0.20)\end{array}$ \\
\hline Business Model & $\begin{array}{l}0.92 \\
(0.17)\end{array}$ & $\begin{array}{l}0.83 \\
(0.14)\end{array}$ & $\begin{array}{l}0.90 \\
(0.10)\end{array}$ & $\begin{array}{l}-0.61 \\
(0.39)\end{array}$ & $\begin{array}{l}-0.30 \\
(0.60)\end{array}$ & $\begin{array}{l}-0.02 \\
(0.25)\end{array}$ \\
\hline External Certification & $\begin{array}{l}0.76 \\
(0.21)\end{array}$ & $\begin{array}{l}1.17 \\
(0.23)\end{array}$ & $\begin{array}{l}1.00 \\
(0.12)\end{array}$ & $\begin{array}{l}-0.45^{*} \\
(0.23)\end{array}$ & $\begin{array}{l}0.31 \\
(0.39)\end{array}$ & $\begin{array}{l}-0.33 * * \\
(0.16)\end{array}$ \\
\hline Product Development & 1.07 & 1.18 & 1.10 & 0.58 & 0.16 & $0.32 * *$ \\
\hline
\end{tabular}


Table 7 (continued)

Panel C: Information and communication

\begin{tabular}{|c|c|c|c|c|c|c|}
\hline \multirow[b]{2}{*}{ Variable lag } & \multicolumn{3}{|c|}{ Investments (\# per day) } & \multicolumn{3}{|c|}{$\operatorname{Ln}($ Amount in $€)$} \\
\hline & $\begin{array}{l}\text { Model } 1 \\
\text { None } \\
(0.15)\end{array}$ & $\begin{array}{l}\text { Model } 2 \\
1 \text { day } \\
(0.19)\end{array}$ & $\begin{array}{l}\text { Model } 3 \\
1 \text { week } \\
(0.07)\end{array}$ & $\begin{array}{l}\text { Model } 4 \\
\text { None } \\
(0.39)\end{array}$ & $\begin{array}{l}\text { Model } 5 \\
1 \text { day } \\
(0.31)\end{array}$ & $\begin{array}{l}\text { Model } 6 \\
1 \text { week } \\
(0.16)\end{array}$ \\
\hline Cooperation Projects & $\begin{array}{l}1.05 \\
(0.26)\end{array}$ & $\begin{array}{l}0.79 \\
(0.12)\end{array}$ & $\begin{array}{l}0.77 \\
(0.18)\end{array}$ & $\begin{array}{l}-0.35 \\
(0.35)\end{array}$ & $\begin{array}{l}-0.22 \\
(0.35)\end{array}$ & $\begin{array}{l}-0.45^{* *} \\
(0.21)\end{array}$ \\
\hline Campaign Development & $\begin{array}{l}1.19 \\
(0.16)\end{array}$ & $\begin{array}{l}1.16 \\
(0.29)\end{array}$ & $\begin{array}{l}1.36^{* *} \\
(0.20)\end{array}$ & $\begin{array}{l}-0.34 \\
(0.33)\end{array}$ & $\begin{array}{l}0.59 \\
(0.48)\end{array}$ & $\begin{array}{l}0.24 \\
(0.25)\end{array}$ \\
\hline New Funding & $\begin{array}{l}0.72 \\
(0.37)\end{array}$ & $\begin{array}{l}0.55 \\
(0.20)\end{array}$ & $\begin{array}{l}1.41 \\
(0.39)\end{array}$ & $\begin{array}{l}1.13^{*} \\
(0.61)\end{array}$ & $\begin{array}{l}-1.02 \\
(0.95)\end{array}$ & $\begin{array}{l}-0.09 \\
(0.49)\end{array}$ \\
\hline Business Development & $\begin{array}{l}1.19 \\
(0.18)\end{array}$ & $\begin{array}{l}1.16 \\
(0.17)\end{array}$ & $\begin{array}{l}1.17 \\
(0.11)\end{array}$ & $\begin{array}{l}0.42 \\
(0.26)\end{array}$ & $\begin{array}{l}0.43 \\
(0.38)\end{array}$ & $\begin{array}{l}0.51 * * * \\
(0.13)\end{array}$ \\
\hline Promotions & $\begin{array}{l}1.12 \\
(0.14)\end{array}$ & $\begin{array}{l}0.92 \\
(0.18)\end{array}$ & $\begin{array}{l}1.15 \\
(0.16)\end{array}$ & $\begin{array}{l}0.39 \\
(0.45)\end{array}$ & $\begin{array}{l}-0.37 \\
(0.53)\end{array}$ & $\begin{array}{l}0.37 \\
(0.31)\end{array}$ \\
\hline $\begin{array}{l}\text { Baseline and fixed effects } \\
\text { Log Likelihood }\end{array}$ & $\begin{array}{l}\text { Yes } * * * \\
-12,520.00\end{array}$ & $\begin{array}{l}\text { Yes } * * * \\
-12,535.94\end{array}$ & $\begin{array}{l}\text { Yes*** } \\
-12,523.06\end{array}$ & Yes*** & Yes*** & Yes*** \\
\hline Adj. $R^{2}$ & & & & 0.14 & 0.14 & 0.14 \\
\hline$N$ Investments days & 5209 & 5209 & 5209 & 5201 & 5201 & 5201 \\
\hline$N$ Campaigns & 70 & 70 & 70 & 71 & 71 & 71 \\
\hline
\end{tabular}

The method of estimation in columns (1) to (3) is the negative binomial fixed effects panel estimator (standard errors are bootstrapped) and in columns (4) to (6) the OLS fixed effects panel estimator (standard errors are clustered on campaign level). Standard errors are reported in brackets

Significance levels for coefficients: $* *<5 \%, * * *<1 \%$ 
Table 8 Effects of update categories by portal

Panel A: Seedmatch

\begin{tabular}{|c|c|c|c|c|c|c|}
\hline \multirow[b]{2}{*}{$\begin{array}{l}\text { Variable lag } \\
\text { Explanatory variables } \\
\text { (lags according to table head) }\end{array}$} & \multicolumn{3}{|c|}{ Investments (\# per day) } & \multicolumn{3}{|c|}{ Ln(Amount in $€)$} \\
\hline & $\begin{array}{l}\text { Model } 1 \\
\text { None }\end{array}$ & $\begin{array}{l}\text { Model } 2 \\
1 \text { day }\end{array}$ & $\begin{array}{l}\text { Model } 3 \\
1 \text { week }\end{array}$ & $\begin{array}{l}\text { Model } 4 \\
\text { None }\end{array}$ & $\begin{array}{l}\text { Model } 5 \\
1 \text { day }\end{array}$ & $\begin{array}{l}\text { Model } 6 \\
1 \text { week }\end{array}$ \\
\hline Flesch Index & $\begin{array}{l}1.01 \\
(0.25)\end{array}$ & $\begin{array}{l}1.06 \\
(0.28)\end{array}$ & $\begin{array}{l}1.01 \\
(0.01)\end{array}$ & $\begin{array}{l}0.01 \\
(0.30)\end{array}$ & $\begin{array}{l}-0.37 \\
(0.32)\end{array}$ & $\begin{array}{l}0.01 \\
(0.01)\end{array}$ \\
\hline Words / 100 & $\begin{array}{l}1.46 \\
(0.47)\end{array}$ & $\begin{array}{l}1.21 \\
(0.40)\end{array}$ & $\begin{array}{l}0.94 \\
(0.18)\end{array}$ & $\begin{array}{l}0.16 \\
(0.36)\end{array}$ & $\begin{array}{l}0.60 \\
(0.49)\end{array}$ & $\begin{array}{l}0.34 \\
(0.22)\end{array}$ \\
\hline Team & $\begin{array}{l}1.00 \\
(0.00)\end{array}$ & $\begin{array}{l}1.00 \\
(0.00)\end{array}$ & $\begin{array}{l}1.00 \\
(0.00)\end{array}$ & - & $\begin{array}{l}- \\
-\end{array}$ & $\begin{array}{l}- \\
-\end{array}$ \\
\hline Business Model & $\begin{array}{l}0.44 \\
(0.33)\end{array}$ & $\begin{array}{l}1.30 \\
(0.91)\end{array}$ & $\begin{array}{l}1.03 \\
(0.61)\end{array}$ & $\begin{array}{l}-1.01 \\
(0.94)\end{array}$ & $\begin{array}{l}1.42 \\
(1.35)\end{array}$ & $\begin{array}{l}0.29 \\
(1.08)\end{array}$ \\
\hline External Certification & $\begin{array}{l}2.54 \\
(2.11)\end{array}$ & $\begin{array}{l}1.31 \\
(7.91)\end{array}$ & $\begin{array}{l}0.84 \\
(0.52)\end{array}$ & $\begin{array}{l}2.03 * * \\
(0.88)\end{array}$ & $\begin{array}{l}-1.15 \\
(1.57)\end{array}$ & $\begin{array}{l}-2.03^{* * * *} \\
(0.75)\end{array}$ \\
\hline Product Development & $\begin{array}{l}0.52 \\
(0.46)\end{array}$ & $\begin{array}{l}0.68 \\
(0.63)\end{array}$ & $\begin{array}{l}0.79 \\
(0.41)\end{array}$ & $\begin{array}{l}0.73 \\
(1.10)\end{array}$ & $\begin{array}{l}0.88 \\
(1.29)\end{array}$ & $\begin{array}{l}-0.77 \\
(0.59)\end{array}$ \\
\hline Cooperation Projects & $\begin{array}{l}1.74 \\
(1.62)\end{array}$ & $\begin{array}{l}0.94 \\
(0.66)\end{array}$ & $\begin{array}{l}1.44 \\
(0.53)\end{array}$ & $\begin{array}{l}0.32 \\
(1.74)\end{array}$ & $\begin{array}{l}-0.23 \\
(0.71)\end{array}$ & $\begin{array}{l}1.34 * * * \\
(0.47)\end{array}$ \\
\hline Campaign Development & $\begin{array}{l}1.40 \\
(0.82)\end{array}$ & $\begin{array}{l}2.49 \\
(2.06)\end{array}$ & $\begin{array}{l}1.91 \\
(1.04)\end{array}$ & $\begin{array}{l}1.86^{* * *} \\
(0.90)\end{array}$ & $\begin{array}{l}1.94 * \\
(1.06)\end{array}$ & $\begin{array}{l}0.60 \\
(0.57)\end{array}$ \\
\hline New Funding & $\begin{array}{l}0.16 \\
(0.87)\end{array}$ & $\begin{array}{l}0.28 \\
(1.72)\end{array}$ & $\begin{array}{l}0.83 \\
(0.73)\end{array}$ & $\begin{array}{l}-2.17 \\
(2.91)\end{array}$ & $\begin{array}{l}-0.22 \\
(2.48)\end{array}$ & $\begin{array}{l}-0.14 \\
(0.87)\end{array}$ \\
\hline Business Development & $\begin{array}{l}0.34 \\
(0.35)\end{array}$ & $\begin{array}{l}1.07 \\
(0.64)\end{array}$ & $\begin{array}{l}1.26 \\
(0.40)\end{array}$ & $\begin{array}{l}-1.73 * \\
(1.03)\end{array}$ & $\begin{array}{l}1.08^{*} \\
(0.60)\end{array}$ & $\begin{array}{l}0.94 * * \\
(0.41)\end{array}$ \\
\hline Promotions & $\begin{array}{l}0.37 \\
(0.52)\end{array}$ & $\begin{array}{l}0.75 \\
(0.80)\end{array}$ & $\begin{array}{l}0.88 \\
(0.45)\end{array}$ & $\begin{array}{l}-1.27 \\
(1.36)\end{array}$ & $\begin{array}{l}-0.02 \\
(1.40)\end{array}$ & $\begin{array}{l}-0.14 \\
(0.47)\end{array}$ \\
\hline $\begin{array}{l}\text { Baseline and fixed effects } \\
\text { Log likelihood }\end{array}$ & $\begin{array}{l}\text { Yes*** } \\
-12,529.63\end{array}$ & $\begin{array}{l}\text { Yes*** } \\
-12,525.12\end{array}$ & $\begin{array}{l}\text { Yes*** } \\
-12,521.54\end{array}$ & Yes*** & Yes*** & Yes*** \\
\hline Adj. $R^{2}$ & & & & 0.14 & 0.14 & 0.15 \\
\hline$N$ Investments days & 5209 & 5209 & 5209 & 5201 & 5201 & 5201 \\
\hline$N$ Campaigns & 70 & 70 & 70 & 71 & 71 & 71 \\
\hline
\end{tabular}

Panel B: Companisto

\begin{tabular}{|c|c|c|c|c|c|c|}
\hline \multirow[b]{2}{*}{$\begin{array}{l}\text { Variable lag } \\
\text { Explanatory variables } \\
\text { (lags according to table head) }\end{array}$} & \multicolumn{3}{|c|}{ Investments (\# per day) } & \multicolumn{3}{|c|}{ Ln(Amount in $€)$} \\
\hline & $\begin{array}{l}\text { Model } 1 \\
\text { None }\end{array}$ & $\begin{array}{l}\text { Model } 2 \\
1 \text { day }\end{array}$ & $\begin{array}{l}\text { Model } 3 \\
1 \text { week }\end{array}$ & $\begin{array}{l}\text { Model } 4 \\
\text { None }\end{array}$ & $\begin{array}{l}\text { Model } 5 \\
1 \text { day }\end{array}$ & $\begin{array}{l}\text { Model } 6 \\
1 \text { week }\end{array}$ \\
\hline Flesch Index & $\begin{array}{l}1.02 \\
(0.04)\end{array}$ & $\begin{array}{l}1.07 * * \\
(0.03)\end{array}$ & $\begin{array}{l}1.00 \\
(0.00)\end{array}$ & $\begin{array}{l}0.05 \\
(0.08)\end{array}$ & $\begin{array}{l}0.14 \\
(0.09)\end{array}$ & $\begin{array}{l}0.01 \\
(0.01)\end{array}$ \\
\hline Words / 100 & $\begin{array}{l}0.99 \\
(0.03)\end{array}$ & $\begin{array}{l}0.99 \\
(0.03)\end{array}$ & $\begin{array}{l}0.97 \\
(0.03)\end{array}$ & $\begin{array}{l}0.11 * \\
(0.07)\end{array}$ & $\begin{array}{l}-0.02 \\
(0.08)\end{array}$ & $\begin{array}{l}-0.04 \\
(0.06)\end{array}$ \\
\hline Team & 1.04 & 0.87 & 1.10 & -0.34 & -0.22 & $0.38^{*}$ \\
\hline
\end{tabular}


Table 8 (continued)

Panel B: Companisto

\begin{tabular}{|c|c|c|c|c|c|c|}
\hline \multirow[b]{2}{*}{ Variable lag } & \multicolumn{3}{|c|}{ Investments (\# per day) } & \multicolumn{3}{|c|}{$\operatorname{Ln}($ Amount in $€)$} \\
\hline & $\begin{array}{l}\text { Model } 1 \\
\text { None } \\
(0.13)\end{array}$ & $\begin{array}{l}\text { Model } 2 \\
1 \text { day } \\
(0.10)\end{array}$ & $\begin{array}{l}\text { Model } 3 \\
1 \text { week } \\
(0.13)\end{array}$ & $\begin{array}{l}\text { Model } 4 \\
\text { None } \\
(0.30)\end{array}$ & $\begin{array}{l}\text { Model } 5 \\
1 \text { day } \\
(0.33)\end{array}$ & $\begin{array}{l}\text { Model } 6 \\
1 \text { week } \\
(0.21)\end{array}$ \\
\hline Business Model & $\begin{array}{l}1.10 \\
(0.16)\end{array}$ & $\begin{array}{l}0.93 \\
(0.10)\end{array}$ & $\begin{array}{l}0.91 * * \\
(0.04)\end{array}$ & $\begin{array}{l}-0.44 \\
(0.30)\end{array}$ & $\begin{array}{l}-0.36 \\
(0.30)\end{array}$ & $\begin{array}{l}-0.07 \\
(0.18)\end{array}$ \\
\hline External Certification & $\begin{array}{l}0.80 \\
(0.13)\end{array}$ & $\begin{array}{l}1.07 \\
(0.13)\end{array}$ & $\begin{array}{l}1.15^{*} \\
(0.09)\end{array}$ & $\begin{array}{l}-0.51 * * * \\
(0.15)\end{array}$ & $\begin{array}{l}-0.18 \\
(0.25)\end{array}$ & $\begin{array}{l}-0.23 \\
(0.18)\end{array}$ \\
\hline Product Development & $\begin{array}{l}0.95 \\
(0.12)\end{array}$ & $\begin{array}{l}1.05 \\
(0.16)\end{array}$ & $\begin{array}{l}1.08 \\
(0.07)\end{array}$ & $\begin{array}{l}0.13 \\
(0.31)\end{array}$ & $\begin{array}{l}0.18 \\
(0.24)\end{array}$ & $\begin{array}{l}0.20 \\
(0.14)\end{array}$ \\
\hline Cooperation Projects & $\begin{array}{l}1.15 \\
(0.15)\end{array}$ & $\begin{array}{l}1.03 \\
(0.06)\end{array}$ & $\begin{array}{l}0.95 \\
(0.09)\end{array}$ & $\begin{array}{l}0.19 \\
(0.22)\end{array}$ & $\begin{array}{l}0.40 * \\
(0.21)\end{array}$ & $\begin{array}{l}0.06 \\
(0.18)\end{array}$ \\
\hline Campaign Development & $\begin{array}{l}1.15 \\
(0.10)\end{array}$ & $\begin{array}{l}1.15 \\
(0.18)\end{array}$ & $\begin{array}{l}1.12 \\
(0.09)\end{array}$ & $\begin{array}{l}-0.20 \\
(0.23)\end{array}$ & $\begin{array}{l}0.22 \\
(0.28)\end{array}$ & $\begin{array}{l}0.02 \\
(0.19)\end{array}$ \\
\hline New Funding & $\begin{array}{l}0.81 \\
(0.23)\end{array}$ & $\begin{array}{l}1.50^{* * *} \\
(0.30)\end{array}$ & $\begin{array}{l}1.52 * * \\
(0.29)\end{array}$ & $\begin{array}{l}0.48 \\
(0.50)\end{array}$ & $\begin{array}{l}0.56 * * \\
(0.24)\end{array}$ & $\begin{array}{l}0.53 * * \\
(0.22)\end{array}$ \\
\hline Business Development & $\begin{array}{l}1.24 * * \\
(0.12)\end{array}$ & $\begin{array}{l}1.10 \\
(0.17)\end{array}$ & $\begin{array}{l}1.16 \\
(0.11)\end{array}$ & $\begin{array}{l}0.23 \\
(0.25)\end{array}$ & $\begin{array}{l}0.24 \\
(0.29)\end{array}$ & $\begin{array}{l}0.31 * * \\
(0.15)\end{array}$ \\
\hline Promotions & $\begin{array}{l}1.15 \\
(0.13)\end{array}$ & $\begin{array}{l}1.01 \\
(0.12)\end{array}$ & $\begin{array}{l}1.12 \\
(0.08)\end{array}$ & $\begin{array}{l}0.36 \\
(0.23)\end{array}$ & $\begin{array}{l}0.32 \\
(0.26)\end{array}$ & $\begin{array}{l}0.30 * \\
(0.17)\end{array}$ \\
\hline $\begin{array}{l}\text { Baseline and fixed effects } \\
\text { Log likelihood }\end{array}$ & $\begin{array}{l}\text { Yes }{ }^{* * *} \\
-12,523.88\end{array}$ & $\begin{array}{l}\text { Yes*** } \\
-12,527.25\end{array}$ & $\begin{array}{l}\text { Yes*** } \\
-12,486.08\end{array}$ & Yes*** & Yes*** & Yes*** \\
\hline Adj. $R^{2}$ & & & & 0.14 & 0.14 & 0.14 \\
\hline$N$ Investments days & 5209 & 5209 & 5209 & 5201 & 5201 & 5201 \\
\hline$N$ Campaigns & 70 & 70 & 70 & 71 & 71 & 71 \\
\hline
\end{tabular}

The method of estimation in columns (1) to (3) is the negative binomial fixed effects panel estimator (standard errors are bootstrapped) and in columns (4) to (6) the OLS fixed effects panel estimator (standard errors are clustered on campaign level). Standard errors are reported in brackets.

Significance levels for coefficients: $* *<5 \%, * * *<1 \%$

Open Access This article is distributed under the terms of the Creative Commons Attribution 4.0 International License (http:// creativecommons.org/licenses/by/4.0/), which permits unrestricted use, distribution, and reproduction in any medium, provided you give appropriate credit to the original author(s) and the source, provide a link to the Creative Commons license, and indicate if changes were made.

\section{References}

Agrawal, A., Catalini, C., \& Goldfarb, A. (2015). Crowdfunding: geography, social networks, and the timing of investment decisions. Journal of Economics \& Management Strategy, 24(2), 253-274. doi:10.1111/jems.12093.
Ahlers, G. K., Cumming, D., Günther, C., \& Schweizer, D. (2015). Signaling in equity crowdfunding. Entrepreneurship Theory and Practice, 39(4), 955-980. doi:10.2139/ssrn.2161587.

Audretsch, D. B., Bönte, W., \& Mahagaonkar, P. (2012). Financial signaling by innovative nascent ventures: the relevance of patents and prototypes. Research Policy, 41(8), 1407-1421. doi:10.1016/j.respol.2012.02.003.

Baltagi, B. (2008). Econometric analysis of panel data. West Sussex: Wiley.

Baum, J. A. C., \& Silverman, B. S. (2004). Picking winners or building them? Alliance, intellectual, and human capital as selection criteria in venture financing and performance of biotechnology startups. Journal of Business Venturing, 19(3), 411-436. doi:10.1016/S0883-9026(03)00038-7.

Belleflamme, P., Lambert, T., \& Schwienbacher, A. (2014). Crowdfunding: tapping the right crowd. Journal of 
Business Venturing, 29(5), 585-609. doi:10.1016/j. jbusvent.2013.07.003.

Bernstein, S., Korteweg, A. G., \& Laws, K. (2017). Attracting early stage investors: evidence from a randomized field experiment. Journal of Finance, 72(2), 509-538. doi:10.1111 /jofi. 12470.

Block, J. H., De Vries, G., Schumann, J. H., \& Sandner, P. (2014). Trademarks and venture capital valuation. Journal of Business Venturing, 29(4), 525-542. doi:10.1016/j. jbusvent.2013.07.006.

Block, J., Colombo, M., Cumming, D., \& Vismara, S. (2017a). New players in entrepreneurial finance and why they are there. Small Business Economics, forthcoming. doi:10.1007 /s11187-016-9826-6.

Block, J., Fisch, C., \& van Praag, M. (2017b). The Schumpeterian entrepreneur: a review of the empirical evidence on the antecedents, behavior, and consequences on innovative entrepreneurship. Industry and Innovation, 31(8), 793-801. doi:10.1080/13662716.2016.1216397.

Boocock, G., \& Woods, M. (1997). The evaluation criteria used by venture capitalists: evidence from a UK venture fund. International Small Business Journal, 16(1), 36-57. doi: $10.1177 / 0266242697161003$.

Branzei, O., Ursacki-Bryant, T. J., Vertinsky, I., \& Zhang, W. (2004). The formation of green strategies in chinese firms: matching corporate environmental responses and individual principles. Strategic Management Journal, 25(11), 10751095. doi:10.1002/smj.409.

Busenitz, L. W., Fiet, J. O., \& Moesel, D. D. (2005). Signaling in venture capitalist - new venture decisions: does it indicate long-term venture outcomes? Entrepreneurship Theory and Practice, 29(1), 1-12. doi:10.1111/j.1540-6520.2005.00066.x.

Carter, S. M. (2006). The interaction of top management group, stakeholder, and situational factors on certain corporate reputation management activities. Journal of Management Studies, 43(3), 1145-1176. doi:10.1111/j.14676486.2006.00632.x.

Certo, S. T. (2003). Influencing initial public offering investors with prestige: signaling with board structures. Academy of Management Review, 28(3), 432-446. doi:10.5465 /AMR.2003.10196754.

Cholakova, M., \& Clarysse, B. (2015). Does the possibility to make equity investments in crowdfunding projects crowd out reward-based investments? Entrepreneurship Theory and Practice, 39(1), 145-172. doi:10.1111/etap.12139.

Colombo, M. G., Franzoni, C., \& Rossi-Lamastra, C. (2015). Internal social capital and the attraction of early contributions in crowdfunding. Entrepreneurship Theory and Practice, 39(1), 75-100. doi:10.1111/etap.12118.

Connelly, B. L., Certo, S. T., Ireland, R. D., \& Reutzel, C. R. (2011). Signaling theory: a review and assessment. Journal of Management, 37(1), 39-67. doi:10.1177 /0149206310388419.

Courtis, J. K. (1995). Readability of annual reports: Western versus Asian evidence. Accounting, Auditing \& Accountability Journal, 8(2), 4-17. doi:10.1108 /09513579510086795.

Cumming, D. \& Zhang, Y. (2016). Are crowdfunding platforms active and effective intermediaries? SSRN Working Paper, No. 2882026. Available at SSRN: https://ssrn. com/abstract=2882026.
Dorfleitner, G., Hornuf, L. \& Weber, M. (2017). Dynamics of investor communication in equity crowdfunding, mimeo.

Doshi, A. (2014). The impact of high performance outliers on twosided platforms: evidence from crowdfunding, SSRN Working Paper, No. 2422111. Available at SSRN: http://ssrn.com/abstract=2422111.

Fischer, E., \& Reuber, A. R. (2014). Online entrepreneurial communication: mitigating uncertainty and increasing differentiation via twitter. Journal of Business Venturing, 29(4), 565583. doi:10.1016/j.jbusvent.2014.02.004.

Fleiss, J. L., Levin, B., \& Paik, M. C. (2003). Statistical methods for rates and proportions (3rd ed.). Hoboken: Wiley.

Flesch, R. (1948). A new readability yardstick. Journal of Applied Psychology, 32(3), 221-233. doi:10.1037/h0057532.

Franke, N., Gruber, M., Harhoff, D., \& Henkel, J. (2008). Venture capitalists' evaluations of start-up teams: trade-offs, knockout criteria, and the impact of VC experience. Entrepreneurship Theory and Practice, 32(3), 459-483. doi:10.1111/j.1540-6520.2008.00236.x.

Gao, Q., \& Lin, M. (2014). Linguistic features and peer-to-peer loan quality: a machine learning approach. SSRN Working Paper, No. 2446114. Available at SSRN: http://papers.ssrn. $\mathrm{com} / \mathrm{sol} 3 /$ papers.cfm?abstract id=2446114.

Gao, H., Darroch, J., Mather, D., \& MacGregor, A. (2008). Signaling corporate strategy in IPO communication: a study of biotechnology IPOs on the NASDAQ. The Journal of Business Communication, 45(1), 3-30. doi:10.1177 10021943607309349.

Gioia, D. A., Corley, K. G., \& Hamilton, A. L. (2012). Seeking qualitative rigor in inductive research: notes on the Gioia methodology. Organizational Research Methods, 16(1), 15-31. doi:10.1177/1094428112452151.

Greiner, M. E., \& Wang, H. (2010). Building consumer-toconsumer trust in E-finance marketplaces: an empirical analysis. International Journal of Electronic Commerce, 15(2), 105-136. doi:10.2753/JEC1086-4415150204.

Gulati, R., \& Higgins, M. C. (2003). Which ties matter when? The contingent effects of interorganizational partnerships on IPO success. Strategic Management Journal, 24(2), 127-144. doi:10.1002/smj.287.

Hemer, J., Schneider, U., Dornbusch, F., \& Frey, S. (2011). Crowdfunding und andere Formen Informeller Mikrofinanzierung in der Projekt-und Innovationsfinanzierung. Stuttgart: Fraunhofer Verlag.

Highhouse, S., Thornbury, E. E., \& Little, I. S. (2007). Socialidentity functions of attraction to organizations. Organizational Behavior and Human Decision Processes, 103(1), 134-146. doi:10.1016/j.obhdp.2006.01.001.

Hornuf, L., \& Schwienbacher, A. (2015). Portal design and funding dynamics in crowdinvesting. Research Papers in Economics, 9(15) and SSRN Working Paper, No. 2612998. Available at SSRN: http://ssrn.com/abstract=2612998.

Hornuf, L., \& Schwienbacher, A. (2016). Crowdinvesting: angel investing for the masses? In H. Landström \& C. Mason (Eds.), Handbook of Research on Business Angels (pp. 381-397). Cheltenham: Edward Elgar.

Janney, J. J., \& Folta, T. B. (2003). Signaling through private equity placements and its impact on the valuation of biotechnology firms. Journal of Business Venturing, 18(3), 361-380. doi:10.1016/S0883-9026(02)00100-3. 
Janney, J. J., \& Folta, T. B. (2006). Moderating effects of investor experience on the signaling value of private equity placements. Journal of Business Venturing, 21(1), 27-44. doi:10.1016/j.jbusvent.2005.02.008.

Jell, F., Block, J. H., \& Henkel, J. (2011). Innovativität als Kriterium bei Venture-Capital-Investitionsentscheidungen. Kredit und Kapital, 44(4), 509-541. doi:10.3790/kuk.44.4.509.

Kickstarter (2012). Blockbuster Effects. Available at: http://www. kickstarter.com/blog/blockbuster-effects.

Kim, K., \& Viswanathan, S.. (2013). The experts in the crowd: the role of reputable investors in a crowdfunding market. TPRC 41: The 41st Research Conference on Communication, Information and Internet Policy. Available at SSRN: http://ssrn.com/abstract=2258243.

Kollmann, T., \& Kuckertz, A. (2006). Investor relations for startups: an analysis of venture capital investors' communicative needs. International Journal of Technology Management, 34(1), 47-62. doi:10.1504/IJTM.2006.009447.

Kromidha, E., \& Robson, P. (2016). Social identity and signalling success factors in online crowdfunding. Entrepreneurship \& Regional Development, 28(9-10), 605-629. doi:10.1080 /08985626.2016.1198425.

Kuppuswamy, V., \& Bayus, B. L. (2017). Crowdfunding creative ideas: The dynamics of project backers. In D. Cumming \& L. Hornuf (Eds.), The Economics of Crowdfunding: Startups, Portals, and Investor Behavior (forthcoming). London: Palgrave Macmillan.

Landis, J. R., \& Koch, G. G. (1977). The measurement of observer agreement for categorical data. Biometrics, 33(1), 159-174. doi: $10.2307 / 2529310$.

Landström, H. (1992). The relationship between private investors and small firms: an agency theory approach. Entrepreneurship \& Regional Development, 4(3), 199-223. doi:10.1080/08985629200000012.

Lukkarinen, A., Teich, J. E., Wallenius, H., \& Wallenius, J. (2016). Success drivers of online equity crowdfunding campaigns. Decision Support Systems, 87, 26-38. doi:10.1016/j. dss.2016.04.006.

McNamara, G. M., Haleblian, J., \& Dykes, B. J. (2008). The performance implications of participating in an acquisition wave: early mover advantages, bandwagon effects, and the moderating influence of industry characteristics and acquirer tactics. Academy of Management Journal, 51(1), 113-130. doi:10.5465/AMJ.2008.30755057.

Miles, M., \& Huberman, A. M. (1994). Qualitative data analysis: an expanded sourcebook (2nd ed.). Thousand Oaks: Sage.

Mohammadi, A., \& Shafi, K. (2017). Gender differences in the contribution patterns of equity-crowdfunding investors gender differences in the contribution patterns of equitycrowdfunding investors. Small Business Economics, forthcoming. doi:10.1007/s11187-016-9825-7.

Mollick, E. R. (2014). The dynamics of crowdfunding: an exploratory study. Journal of Business Venturing, 29(1), 1-16. doi:10.1016/j.jbusvent.2013.06.005.

Moritz, A., \& Block, J. H. (2015). Crowdfunding: a literature review and research directions. In: Block, J. H., \& Kuckertz, A. (Series Eds.), Brüntje, D., \& Gajda, O. (Vol. Eds.), FGF Studies in Small Business and Entrepreneurship:
Vol. 1. Crowdfunding in Europe - State of the Art in Theory and Practice (pp. 25-53). Cham: Springer Science \& Business Media.

Moritz, A., Block, J. H., \& Lutz, E. (2015). Investor communication in equity-based crowdfunding: a qualitative-empirical study. Qualitative Research in Financial Markets, 7(3), 309-342. doi:10.1108/QRFM-07-2014-0021.

Perkins, S. J., \& Hendry, C. (2005). Ordering top pay: interpreting the signals. Journal of Management Studies, 42(7), 14431468. doi:10.1111/j.1467-6486.2005.00550.x.

Polzin F., Toxopeus H., Stam E. (2017). The wisdom of the crowd in funding. Information heterogeneity and social networks of crowdfunders. Small Business Economics, forthcoming. doi:10.1007/s11187-016-9829-3.

Ralcheva, A., \& Roosenboom, P. (2016). On the road to success in equity crowdfunding. SSRN Working Paper, No. 2727742, Available on SSRN: https://papers.ssrn.com/sol3/papers. cfm?abstract_id=2727742.

Rao, R. S., Chandy, R. K., \& Prabhu, J. C. (2008). The fruits of legitimacy: why some new ventures gain more from innovation than others. Journal of Marketing, 72(4), 58-75.

Ross, S. A. (1977). The determination of financial structure: the incentive signalling approach. Bell Journal of Economics, 8(1), 23-40. doi:10.2307/3003485.

Sapienza, H., \& Korsgaard, M. (1996). Procedural justice in entrepreneur-investor relations. Academy of Management Journal, 39(3), 544-574. doi:10.2307/256655.

Spence, M. (1973). Job market signaling. The Quarterly Journal of Economics, 87(3), 355-374. doi:10.2307/1882010.

Srivastava, J. (2001). The role of inferences in sequential bargaining with one-sided incomplete information: some experimental evidence. Organizational Behavior and Human Decision Processes, 85(1), 166-187. doi:10.1006/obhd.2000.2936.

Vismara, S. (2016a). Equity retention and social network theory in equity crowdfunding. Small Business Economics, 46(4), 579-590. doi:10.1007/s11187-016-9710-4.

Vismara, S. (2016b). Information cascades among investors in equity crowdfunding. Entrepreneurship Theory and Practice, forthcoming. doi:10.1111/etap.12261.

Vulkan, N., Åstebro, T., \& Sierra, M. F. (2016). Equity crowdfunding: a new phenomena. Journal of Business Venturing Insights, 5, 37-49. doi:10.1016/j.jbvi.2016.02.001.

Warner, A. G., Fairbank, J. F., \& Steensma, H. K. (2006). Managing uncertainty in a formal standards-based industry: a real options perspective on acquisition timing. Journal of Management, 32(2), 279-298. doi:10.1177 /0149206305280108.

Wheat, R. E., Wang, Y., Byrnes, J. E., \& Ranganathan, J. (2013). Raising money for scientific research through crowdfunding. Trends in Ecology \& Evolution, 28(2), 71-72. doi:10.1016/j. tree.2012.11.001.

Wu, S., Wang, B., \& Li, Y. (2015). How to attract the crowd in crowdfunding? International Journal of Entrepreneurship and Small Business, 24(3), 322-334. doi:10.1504 /IJESB.2015.067465.

Xu, A., Yang, X., Rao, H., Fu, W. T., Huang, S. W., \& Bailey, B. P. (2014). Show me the money! An analysis of project updates during crowdfunding campaigns. In Proceedings of the $32^{\text {nd }}$ 
Annual ACM Conference for Human Factors in Computing Systems, ACM: 591-600. Available at: https://pdfs. semanticscholar.org/34a6/bb3c6ed524f0cdb56cd7c11 fe8159ef595a5.pdf.
Zimmerman, M. A., \& Zeitz, G. J. (2002). Beyond survival: achieving new venture growth by building legitimacy. Academy of Management Review, 27(3), 414-431. doi:10.5465/AMR.2002.7389921. 